\title{
Pediatric Hodgkin Iymphoma- biomarkers, drugs, and clinical trials for translational science and medicine
}

\author{
Poonam Nagpal ${ }^{1}$, Mohamed R. Akl ${ }^{1}$, Nehad M. Ayoub², Tatsunari Tomiyama ${ }^{1}$, \\ Tasheka Cousins ${ }^{1}$, Betty Tai $^{1}$, Nicole Carroll ${ }^{1}$, Themba Nyrenda ${ }^{3}$, Pritish \\ Bhattacharyya $^{4}$, Michael B. Harris ${ }^{5}$, Andre Goy ${ }^{6}$, Andrew Pecora ${ }^{6}$ and K. Stephen \\ Suh $^{1,3}$ \\ 1 The Genomics and Biomarkers Program, The John Theurer Cancer Center, Hackensack University Medical Center, \\ Hackensack, NJ, USA \\ 2 Department of Clinical Pharmacy, Jordan University of Science and Technology, Irbid, Jordan \\ ${ }^{3}$ Department of Research, Hackensack University Medical Center, Hackensack, NJ, USA \\ ${ }^{4}$ Department of Pathology, Hackensack University Medical Center, Hackensack, NJ, USA \\ ${ }^{5}$ Department of Pediatrics, Hackensack University Medical Center, Hackensack, NJ, USA \\ ${ }^{6}$ Clinical Divisions, The John Theurer Cancer Center, Hackensack University Medical Center, Hackensack, NJ, USA \\ Correspondence to: K. Stephen Suh, email: Kwangsun.Suh@hackensackmeridian.org \\ Keywords: Hodgkin lymphoma, pediatric, adolescent, biomarker, tumor microenvironment \\ Received: March 23, $2016 \quad$ Accepted: August 18, $2016 \quad$ Published: August 22, 2016
}

\section{ABSTRACT}

Hodgkin lymphoma (HL) is a lymphoid malignancy that is typically derived from germinal-center B cells. EBV infection, mutations in NF-KB pathway genes, and genetic susceptibility are known risk factors for developing HL. CD30 and NF-KB have been identified as potential biomarkers in pediatric $\mathrm{HL}$ patients, and these molecules may represent therapeutic targets. Although current risk adapted and response based treatment approaches yield overall survival rates of $>95 \%$, treatment of relapse or refractory patients remains challenging. Targeted $\mathrm{HL}$ therapy with the antibody-drug conjugate Brentuximab vedotin ( $\mathrm{Bv}$ ) has proven to be superior to conventional salvage chemotherapy and clinical trials are being conducted to incorporate Bv into frontline therapy that substitutes Bv for alkylating agents to minimize secondary malignancies. The appearance of secondary malignancies has been a concern in pediatric $\mathrm{HL}$, as these patients are at highest risk among all childhood cancer survivors. The risk of developing secondary leukemia following childhood HL treatment is 10.4 to 174.8 times greater than the risk in the general pediatric population and the prognosis is significantly poorer than the other hematological malignancies with a mortality rate of nearly $100 \%$. Therefore, identifying clinically valuable biomarkers is of utmost importance to stratify and select patients who may or may not need intensive regimens to maintain optimal balance between maximal survival rates and averting late effects. Here we discuss epidemiology, risk factors, staging, molecular and genetic prognostic biomarkers, treatment for low and high-risk patients, and the late occurrence of secondary malignancies in pediatric $\mathrm{HL}$.

\section{INTRODUCTION}

Hodgkin lymphoma (HL) is a unique monoclonal lymphoid malignancy that is characterized by the presence of typical bi/multinucleated Reed-Sternberg cells and their variants, mononucleated Hodgkin cells, collectively known as Hodgkin Reed-Sternberg cells (HRS). Most
HRS cells express CD15 and CD30 (85\% and 100\%, respectively in HL cases). HRS cells have a B-cell ancestry as revealed by single cell PCR detection of Ig gene rearrangements [1]; and somatic mutations in the variable region of heavy and light chain Ig genes are suggestive of a late germinal or post-germinal center B-cell origin [2-4]. Despite their B-cell origin, HRS cells typically lack core 
Table 1: Comparison of demographic and clinical characteristics between different age groups of Hodgkin lymphoma (HL) patients

\begin{tabular}{|c|c|c|c|}
\hline Characteristics [Ref] & Pediatric HL & AYA (Adolescent and young adult) HL & Adult HL \\
\hline Age & $0-14$ & $15-34$ & $>35$ \\
\hline Prevalence [13] & 6/million/yr & 32/million/yr & 28/million/yr \\
\hline $\begin{array}{l}\text { Predominant gender } \\
{[13,149]}\end{array}$ & Male & Female (15-19), Male $(<20)$ & Male (common: $55-74$ yr) \\
\hline Histology [16] & $\begin{array}{l}\text { Mixed-cellularity } \quad \text { Hodgkin } \\
\text { lymphoma }(22 \%)\end{array}$ & $\begin{array}{l}\text { Nodular sclerosis Hodgkin lymphoma } \\
(76 \%)\end{array}$ & $\begin{array}{lr}\begin{array}{l}\text { Nodular } \\
\text { Hodgkin } \\
(61 \%)\end{array} & \text { sclerosis } \\
\end{array}$ \\
\hline $\begin{array}{l}\text { Predominant stage at } \\
\text { Diagnosis [16] }\end{array}$ & II & II & II \\
\hline $\begin{array}{l}\text { Most } \quad \text { common } \\
\text { symptoms }[16,150]\end{array}$ & $\begin{array}{l}\text { Painless adenopathy involving } \\
\text { supraclavicular or cervical } \\
\text { area }(80 \%)\end{array}$ & Asymptomatic mediastinal disease & $\begin{array}{l}\text { Asymptomatic } \\
\text { lymphadenopathy } \\
(<80 \%) \text {, B symptoms } \\
(40 \%) \text {, Intermittent fever } \\
(35 \%)\end{array}$ \\
\hline $\begin{array}{l}\text { EBV association } \\
{[151] \quad}\end{array}$ & Yes $(<10 y r: 80 \%)$ & No $(<30 \%)$ & $\begin{array}{lll}\text { No }(20-50 & \text { yr }), & \text { Yes } \\
(>60 y r ; 70 \%) & \end{array}$ \\
\hline $\begin{array}{l}\text { Treatment outcome }(5 \\
\left.\text { yr OS }^{a}\right)[16,149]\end{array}$ & $90-95 \%$ & $90 \%$ & $85.90 \%$ \\
\hline
\end{tabular}

${ }^{a}$ OS, Overall Survival

B cell features, including specific signaling molecules that are associated with the B-cell lineage, which are either absent or expressed by only a small subset of cells [5-7]. In addition to the variable B-cell marker expression shown by $\sim 95 \%$ of classical Hodgkin lymphoma (cHL) cases, HRS cells can express markers that are characteristic of other hematopoietic lineages, including dendritic cells, monocytes, and T-cells (5-15\% cHL cases) [8-10]. Though rarely expressed, T-cell markers on HRS cells have been reported to be independently associated with poor prognosis $[10,11]$.

Biologically, HL is similar if not identical in children and adults except for the relative incidence of specific histological subtypes and distinct immune response against HRS cells in tumor microenvironment. HL can be divided into two broad classes based on histologic features and phenotypes: (1) Classical Hodgkin lymphoma (cHL) and (2) Nodular lymphocyte predominant Hodgkin lymphoma (NLPHL). cHL can be further divided into four subtypes: lymphocyte rich (LR), nodular sclerosis (NS), mixed cellularity (MC), and lymphocyte depleted (LD). NLPHL is considered to be a distinct disease entity that is more similar to B-cell non-HL than to cHL [12]. Therefore, this review will focus on $\mathrm{cHL}$.

With the advent of recent advanced treatment and imaging technologies, a cure rate of $>95 \%$ has been achieved for pediatric HL patients. However, the prognosis of relapse/refractory (RR) patients is dismal The secondary malignancy and cardiopulmonary toxicity that can be caused by HL treatment motivated greater focus on therapy refinements that would minimize toxicity while maintaining high cure rates. As such, identification of prognostic biomarkers in pediatric patients that correlate with clinical outcome will increase the understanding of
HL pathology and likely influence therapeutic approaches. In this review, we discuss the main characteristics and prognostic biomarkers in pediatric cHL as well as current treatments and emerging targeted therapies. We also briefly present treatment complications and secondary malignant neoplasms (SMNs) that can occur in long-term survivors of HL.

\section{EPIDEMIOLOGY AND RISK FACTORS}

Childhood HL represents $6 \%$ of all cancers and has an incidence rate of 12 cases/million/year in the $0-14$ year age group with a typical male predominance [13]. Among the demographics of different age groups, HL shows a characteristic bimodal distribution, with the first, larger peak seen for adolescents and young adults (1524 year age group) and a second, smaller peak occurring for adults (around 59 years) (Table 1) [14, 15]. The MC histological subtype, mostly associated with Epstein-Barr virus (EBV), is observed primarily in young children and represents about $20 \%$ of HL; whereas, the NS subtype is seen predominantly in adolescents and young adults and represents about $75 \%$ of HL [16]. Although EBV positivity is not a direct finding of HL, tumor cells are infected with EBV in approximately $30 \%$ and $90 \%$ of all HL cases in developed and developing countries, respectively $[16,17]$. Two key EBV genes involved in the etiology of HL are: latent membrane protein (LMP) 1 (lmpl), which induces constitutive nuclear factor-kappaB (NF- $\kappa \mathrm{B})$ activation by mimicking CD40 receptor [18], and $\operatorname{lmp} 2 A$, which can take over the function of the B-cell receptor (BCR) [19]. Various findings revealed raised antibody titers and EBV DNA detection in HL patients that are suggestive of 
Table 2: Prognostic biomarkers in pediatric Hodgkin lymphoma

\begin{tabular}{|c|c|c|c|c|c|c|c|c|c|}
\hline Biomarker & Function & $\begin{array}{l}\text { Patients } \\
\text { (n) }\end{array}$ & $\begin{array}{l}\text { Median/ } \\
\text { mean Age } \\
\text { (years) }\end{array}$ & Specimen type & Method & $\begin{array}{l}\text { Levels/Expression } \\
\text { pattern }\end{array}$ & Prognosis & Associated with & Ref \\
\hline $\mathrm{p} 53$ & $\begin{array}{l}\text { cell cycle and } \\
\text { apoptosis }\end{array}$ & 54 & 8 & FFPE & $\mathrm{IHC}$ & $\begin{array}{l}81 \% \text { patients } \\
\text { overexpressed }\end{array}$ & $\begin{array}{l}\text { No significant } \\
\text { difference }\end{array}$ & - & {$[37]$} \\
\hline bcl-2 & $\begin{array}{l}\text { anti- and pro- } \\
\text { apoptosis }\end{array}$ & 104 & 14 & TMA & $\mathrm{IHC}$ & $\begin{array}{l}52.4 \% \quad \text { patients } \\
\text { positive }\end{array}$ & $\begin{array}{l}(\downarrow) 0.8 \text { fold } 10 \mathrm{yr} \\
\text { EFS }(P=0.048) \text { in } \\
\text { high risk }\end{array}$ & unfavorable risk & {$[36]$} \\
\hline $\mathrm{Ki}-67$ & proliferation & 121 & 8 & $\begin{array}{l}\text { pretreatment LN } \\
\text { biopsy }\end{array}$ & $\mathrm{IHC}$ & $\begin{array}{l}100 \% \text { cases nuclear } \\
\text { positive expression }\end{array}$ & $\begin{array}{l}(\downarrow) 0.7 \text { fold } 5 \text { yr } \\
\text { FFS in low vs. high } \\
\text { PI (cutoff } 74 \%, P= \\
0.016 \text { ) }\end{array}$ & - & {$[43]$} \\
\hline $\mathrm{Ki}-67$ & proliferation & 224 & 13.7 & biopsy & $\mathrm{IHC}$ & $100 \%$ patients positive & \begin{tabular}{|l|l}
$\begin{array}{l}\text { No significant } \\
\text { difference }\end{array}$ \\
\end{tabular} & $\begin{array}{l}\text { No significant } \\
\text { correlation }\end{array}$ & {$[41]$} \\
\hline IL-10/IL-12 & $\begin{array}{l}\text { anti-inflammatory/ } \\
\text { pro-inflammatory }\end{array}$ & $\begin{array}{l}30 \text { vs. } 30 \\
\text { controls }\end{array}$ & 15.4 & $\begin{array}{l}\text { pretreatment } \\
\text { serum }\end{array}$ & ELISA & $\begin{array}{l}(\uparrow)>2 \text { fold in IL10 } \\
\text { and IL-12 levels in } \\
\text { tumors vs. healthy } \\
\text { control }(p<0.00001)\end{array}$ & - & general symptoms & {$[44]$} \\
\hline $\mathrm{CD} 30+$ cells & proliferation & 96 & 14 & TMA & $\mathrm{IHC}$ & $\begin{array}{l}45 \% \text { cases positive } \\
\text { with }>5 \% \text { cellularity }\end{array}$ & $\begin{array}{l}\text { ( } \downarrow) \text { EFS in high vs. } \\
\text { low CD30+ cells } \\
\text { (cutoff } 5 \%, P= \\
0.048 \text { ) }\end{array}$ & - & {$[46]$} \\
\hline sCD30 & proliferation & 303 & - & $\begin{array}{l}\text { pretreatment } \\
\text { serum }\end{array}$ & ELISA & $\begin{array}{l}(\uparrow) 78.2 \% \text { patients }(> \\
20 \mathrm{U} / \mathrm{mL})\end{array}$ & $\begin{array}{l}(\downarrow) 0.6 \text { fold EFS } \\
\text { high vs. low CD30 } \\
\text { levels (cutoff } 100 \\
\mathrm{U} / \mathrm{mL}, P<0.001 \text { ) }\end{array}$ & $\begin{array}{l}\text { stage, } \\
\text { symptoms, tumor } \\
\text { burden }\end{array}$ & {$[47]$} \\
\hline ICAM-1 (CD-54) & $\begin{array}{l}\text { cell-cell adhesion, } \\
\text { cell-mediated } \\
\text { cytotoxicity }\end{array}$ & 69 vs. 32 & 14 & $\begin{array}{l}\text { pretreatment } \\
\text { serum }\end{array}$ & ELISA & $\begin{array}{l}(\uparrow) 2 \text { fold in tumors vs. } \\
\text { normal controls }(P= \\
.0001) ;(\downarrow) \text { in patients } \\
\text { from diagnosis to CR } \\
(P<0.0001)\end{array}$ & $\begin{array}{l}\text { ( } \downarrow) \text { DFS in high vs. } \\
\text { low ICAM-1 levels } \\
\text { (cutoff } 500 \mathrm{ng} / \mathrm{ml} \text {, } \\
\mathrm{P}=0.016 \text { ) }\end{array}$ & $\begin{array}{l}\text { advanced disease, } \\
\mathrm{B} \quad \text { symptom, } \\
\text { higher ESR, } \\
\text { relapse }\end{array}$ & {$[51]$} \\
\hline ICAM-1 (CD-54) & $\begin{array}{l}\text { cell-cell adhesion, } \\
\text { cell-mediated } \\
\text { cytotoxicity }\end{array}$ & $\begin{array}{l}12 \text { vs. } 8 \\
\text { controls }\end{array}$ & 7.4 & $\begin{array}{l}\text { pretreatment } \\
\text { serum }\end{array}$ & ELISA & $\begin{array}{l}(\uparrow) \sim 7 \text { fold in tumors } \\
\text { vs. control }(p<0.000)\end{array}$ & \begin{tabular}{|l}
$(\uparrow)$ bad outcome \\
(death) in high \\
ICAM-1 levels \\
$(1,894.9+/-149.8$ \\
ng/ml, $P=0.009)$
\end{tabular} & $\begin{array}{l}\text { B symptoms, } \\
\text { LDH levels }\end{array}$ & {$[52]$} \\
\hline ICAM-1 (CD-54) & $\begin{array}{l}\text { cell-cell adhesion, } \\
\text { cell-mediated } \\
\text { cytotoxicity }\end{array}$ & $\begin{array}{l}10 \text { vs. } 12 \\
\text { controls }\end{array}$ & - & $\begin{array}{l}\text { pretreatment } \\
\text { serum }\end{array}$ & ELISA & $\begin{array}{l}(\uparrow) 2 \text { fold in tumors vs. } \\
\text { control }(p<0.01)\end{array}$ & $\begin{array}{l}\text { ( } \downarrow) 0.4 \text { fold } 3 \mathrm{yr} \\
\text { survival in high vs } \\
\text { low ICAM-1 levels } \\
\text { (median } 286.4 \mathrm{ng} / \\
\mathrm{ml}, P<.05)\end{array}$ & high ESR & {$[50]$} \\
\hline & & & & FFPE & $\mathrm{IHC}$ & \begin{tabular}{|l|l}
$75 \%$ positivity in \\
advanced stage
\end{tabular} & - & high serum levels & \\
\hline CD-44 & metastasis & $\begin{array}{l}16 \text { vs. } 12 \\
\text { controls }\end{array}$ & & $\begin{array}{l}\text { pretreatment } \\
\text { serum }\end{array}$ & ELISA & $\begin{array}{l}(\uparrow) \sim 2 \text { fold in tumors } \\
\text { vs. control }(p<0.001) \text {; } \\
(\downarrow) \text { in patients from } \\
\text { diagnosis to CR }(P< \\
0.05)\end{array}$ & $\begin{array}{l}\text { ( } \downarrow) 0.2 \text { fold } 3 \mathrm{yr} \\
\text { OS in high vs. low } \\
\text { ICAM-1 levels } \\
\text { (median 1627 ng/ } \\
\text { ml, } P=0.03 \text { ) }\end{array}$ & $\begin{array}{l}\text { high ESR, } \\
\text { B-symptoms, } \\
\text { advanced-stage } \\
\text { disease }\end{array}$ & {$[54]$} \\
\hline CD-44 & metastasis & $\begin{array}{l}18 \text { vs. } 20 \\
\text { controls }\end{array}$ & - & $\begin{array}{l}\text { pretreatment } \\
\text { serum }\end{array}$ & ELISA & $\begin{array}{l}(\uparrow) \sim 2 \text { fold in tumors } \\
\text { vs. control }(p=0.001)\end{array}$ & - & $\begin{array}{l}\text { LDH levels, } \\
\text { advanced disease }\end{array}$ & {$[53]$} \\
\hline$\alpha$-1-antitrypsin & protease inhibitor & 22 & 14.7 & $\begin{array}{l}\text { pretreatment } \\
\text { serum }\end{array}$ & SELDI & $\begin{array}{l}(\uparrow) 3.5 \text { fold mean } \\
\text { Intensity in stage IV } \\
\text { sera vs. stage II }\end{array}$ & - & advanced stage & {$[56]$} \\
\hline NK cells & immunosurveillance & 38 & 8.5 & tissue sections & $\mathrm{IHC}$ & $\begin{array}{l}\text { Mean CD-57+ cell } \\
\text { number } 173.42 ;(\downarrow) 2 \\
\text { fold in relapsed cases }\end{array}$ & $\begin{array}{l}\text { ( } \downarrow) \text { EFS in low vs. } \\
\text { high CD-57+ cells } \\
\text { (cutoff 150,P }= \\
0.0207) .\end{array}$ & - & {$[57]$} \\
\hline NF-kB & $\begin{array}{l}\text { lymphocyte } \\
\text { proliferation and } \\
\text { survival }\end{array}$ & 102 & 15 & $\begin{array}{l}\text { pretreatment LN } \\
\text { biopsy }\end{array}$ & $\mathrm{IHC}$ & $\begin{array}{l}(\uparrow) \text { cytoplasmic NF- } \\
\kappa B 2 \text { in H/RS cells vs. } \\
\text { controls }\end{array}$ & $\begin{array}{l}(\downarrow) \text { EFS in } \\
\text { increased Rel-B }(P \\
=0.009), \text { NIK }(P= \\
0.015), \text { and A20 }(P \\
=0.03) \text { expression } \\
\end{array}$ & $\begin{array}{l}\text { slow response to } \\
\text { therapy }\end{array}$ & {$[22]$} \\
\hline Heparanase & $\begin{array}{l}\text { metastasis and } \\
\text { angiogenesis }\end{array}$ & 19 & - & $\begin{array}{l}\text { pre and post } \\
\text { treatment blood }\end{array}$ & ELISA & $\begin{array}{l}(\uparrow) 6 \text { fold Heparanase } \\
\text { in patients vs. } \\
\text { control; }(\downarrow) 1.7 \text { fold at } \\
\text { restaging }(P=.035)\end{array}$ & - & $\begin{array}{l}\text { treatment } \\
\text { response }\end{array}$ & {$[67]$} \\
\hline VEGEF & angiogenesis & $\begin{array}{l}22 \text { vs. } 20 \\
\text { controls }\end{array}$ & 13 & $\begin{array}{l}\text { pretreatment } \\
\text { blood }\end{array}$ & ELISA & $\begin{array}{l}(\uparrow)>4 \text { fold VEGEF in } \\
\text { patients vs. controls }(P \\
=0.0001)^{*}\end{array}$ & \begin{tabular}{|l}
$(\uparrow) \quad 5$ fold \\
unsuccessful \\
treatment in high \\
vs. low VEGEF \\
level (cutoff 33.4 \\
pg/ml, $P=0.01$ )* \\
\end{tabular} & - & {$[70]$} \\
\hline VEGEF & angiogenesis & 19 & 10.3 & $\begin{array}{l}\text { pre and post } \\
\text { treatment blood }\end{array}$ & ELISA & $\begin{array}{l}(\uparrow)>6 \text { fold plasma } \\
\text { levels at diagnosis vs. } \\
\text { controls }(p<.0001)\end{array}$ & - & $\begin{array}{l}\text { treatment } \\
\text { response }\end{array}$ & {$[66]$} \\
\hline CD-68+ cells & $\begin{array}{l}\text { survival and } \\
\text { metastasis }\end{array}$ & 74 & - & TMA & $\mathrm{IHC}$ & $\begin{array}{l}100 \% \text { cases }>5 \% \\
\text { CD68+ macrophages; } \\
86 \% \text { cases >25\% } \\
\text { macrophages }\end{array}$ & - & EBV positivity & {$[74]$} \\
\hline
\end{tabular}




\begin{tabular}{|c|c|c|c|c|c|c|c|c|c|}
\hline CD- $163+$ cells & $\begin{array}{l}\text { survival } \\
\text { metastasis }\end{array}$ & 100 & 14 & TMA & $\mathrm{IHC}$ & $\begin{array}{lll}\text { CD68+ve } & \text { cells } \\
\text { number } & 290.81 \text { cells/ } \\
\text { mm2; CD163+ve cells } \\
\text { number } & 164.1 \text { cells/ } \\
\text { mm2 } & \end{array}$ & $\begin{array}{l}\text { ( }) \text { PFS in EBV- } \\
\text { cases with high } \\
\text { CD163+ cells; ( }(\downarrow) \\
5 \text { year OS in high } \\
\text { vs. low CD163/ } \\
\text { CD8 ratio (cutoff 2, } \\
P=0.005 \text { ) }\end{array}$ & $\begin{array}{l}\text { histological type: } \\
\text { MC }\end{array}$ & [72] \\
\hline
\end{tabular}

Abbreviations : CR, Complete Remission; DFS, Disease-free Survival; EBV, Epstein-Barr Virus; EFS, Event Free Survival; ELISA, Enzyme-linked Immunosorbent Assay; ESR, Erythrocyte Sedimentation Rate; FFPE, Formalin-fixed, Paraffinembedded; H/RS, Hodgkin and Reed Sternberg; HL, Hodgkin Lymphoma; IHC, Immunohistochemistry; ISH, In Situ Hybridization; LDH, Lactate Dehydrogenase; LN, Lymph Node; MC, Mixed Cellularity; NF-kB, Nuclear Factor Kappalight-chain-enhancer of Activated B Cells; OS, Overall Survival; PFS, Progression Free Survival; RT-qPCR, Quantitative Reverse Transcription Polymerase Chain Reaction; SD, Standard Deviation; SELDI, Surface-enhanced Laser Desorption/ Ionization; TMA, tumor associated macrophages

*Combined results of HL and NHL

association of EBV with HL $[20,21]$. Additionally, the increased deregulation of the NF- $\mathrm{BB}$ pathway in $\mathrm{EBV}+$ patients relative to EBV- patients is consistent with a role for EBV in the development of HL [22]. In EBV- cases signaling events are complemented by mutations in tumor necrosis factor alpha-induced protein 3 (TNFAIP3), which encodes the NF- $\kappa$ B inhibitor A20 [23]. Despite these findings, the prognostic significance of EBV positivity is puzzling, and is less well investigated in pediatric HL patients. Only a few studies have reported a direct prognostic significance of EBV positivity in HL [24-26], whereas numerous studies reported either no association or better clinical outcome of EBV+ pediatric HL [27-29]. The different outcomes might be attributed to variations in the presence of $\mathrm{EBV}+\mathrm{HL}$ that is related to geography, age, ethnicity, and histological type.

Epidemiologic studies linked the risk of childhood HL to limited social contact, fewer siblings, low housing density, immunodeficiency, viral infection, high fetal growth rate, and familial HL (4.5\% of cases) [30-32]. Genetic susceptibility to HL is strongly supported by a twin study of lymphomas, wherein, monozygotic twins of HL patients had nearly a 100 -fold increased risk of HL, but dizygotic twins had no excess risk suggestive of coinheritance of genetic variants [33]. The co-inheritance of genetic variants and shared childhood environmental effects could confer HL susceptibility was further proven by the 3-fold elevated risk among first-degree relatives of HL patients [32]. The highest familial risk (81-fold) was found in first-degree relatives with a concordant LR subtype [32]. Other genetic risk factors that are associated with familial predisposition to HL, including single nucleotide polymorphisms, are reviewed elsewhere [34].

\section{CURRENT STAGING}

The Ann Arbor staging system with Cotswolds' modification is the current standard for staging HL in children. This system includes four stages wherein Stages I and II indicate limited disease while stages III and IV as advanced disease. Stage I constitutes 19\%, stage II 49\%, stage III $19 \%$, and stage IV $13 \%$ of all pediatric HL cases [16]. HL patients are further stratified into 3 risk groups based on disease stage and extent, disease bulk, and systemic B symptoms (e.g., unexplained persistent fevers, weight loss, or drenching night sweats). According to the Children's Oncology Group (COG) classification, the lowrisk group includes patients with stage IA/IIA without bulk or extranodal extension (E) while patients at intermediaterisk are included in a broad group that encompasses stage IA bulk or E, IB, IIA bulk or E, IIB, IIIA and IVA. Highrisk includes all stage IIIB and IVB patients.

Staging and monitoring of pediatric HL patients is often done using fluorodeoxyglucose (FDG) positron emission tomography (PET)-computed tomography, which integrates functional and anatomic tumor characteristics to help delineate radiotherapy (RT) margins and provide a baseline scan for subsequent response assessment. The primary goals of FDG-PET for interim assessment after initial cycles of chemotherapy are to further refine risk classification and to identify patients who are either cured and do not require RT or need escalated treatment. However, there is no consensus definition and optimum time point for response assessment. In advanced-stage patients, bilateral bone marrow aspirate and biopsies are also required for staging of pediatric HL. Surveillance scans are recommended after completion of therapy to identify early relapse in high-risk patients. The Childhood Hodgkin Lymphoma International Prognostic Score (CHIPS) system described four clinical factors that are predictive of worse event-free survival (EFS): stage IV disease, large mediastinal adenopathy, albumin level $<3.5$ $\mathrm{g} / \mathrm{dL}$, and fever [35]. These findings provided the basis for prospective COG clinical trials. Most pediatric HL research groups also follow the presence of molecular and genetic factors for risk stratification, which informs treatment strategies and improves outcomes. 


\section{MOLECULAR AND GENETIC PROGNOSTIC BIOMARKERS}

Although prognostic biomarkers for pediatric HL have been investigated (Table 2), none have been sufficiently informative to be of significant value in clinical practice. Thus, molecular markers that can identify high-risk patients and predict risk of treatment failure are needed. Moreover, the availability of predictive biomarkers could aid the development of possible therapeutic targets that would help balance treatment outcomes and late effects of therapy. Several putative prognostic factors linked to pediatric HL are discussed below (also see Table 2).

\section{Bcl-2}

B-cell leukemia/lymphoma 2 (Bcl-2) confers a protective advantage by mediating LMP-1-driven immortalization and enabling cells to evade programmed cell death. Approximately $50 \%$ of pediatric HL patients express Bcl-2 [36], and this Bcl-2 positivity is associated with decreased EFS in low-risk patients, and unfavorable risk patients in multivariate analysis [36]. However, some reports suggested that Bcl-2 expression did not affect outcomes [24, 37], and thus the prognostic value of Bcl-2 expression in $\mathrm{HL}$ is unclear.

Ki-67

Several studies documented that high expression levels of the cell proliferation marker Ki-67 are common in HL [38-40] and can negatively impact outcome [40]. However, an immunohistochemical study of 224 pediatric patients enrolled in the German Society for Pediatric Oncology and Hematology (GPOH) HD-90 and HD95 trials found that high Ki-67 expression in HRS cells as well as lymphocytic and histiocytic cells was not related to either advanced clinical stage or poor clinical outcome. Meanwhile, expression of the cell cycle marker repp86, which generally becomes detectable at the G1-S boundary, was low, implying that HRS or lymphocytic and histiocytic cells are arrested in the G1 phase of the cell cycle [41]. Better outcomes in pediatric HL cases that have a high proliferative index are attributed to increased susceptibility of proliferative cells to chemotherapeutic drugs $[17,42,43]$. Therefore, the role of Ki-67 and other cell cycle antigens in HL prognosis remains elusive and requires further investigation.

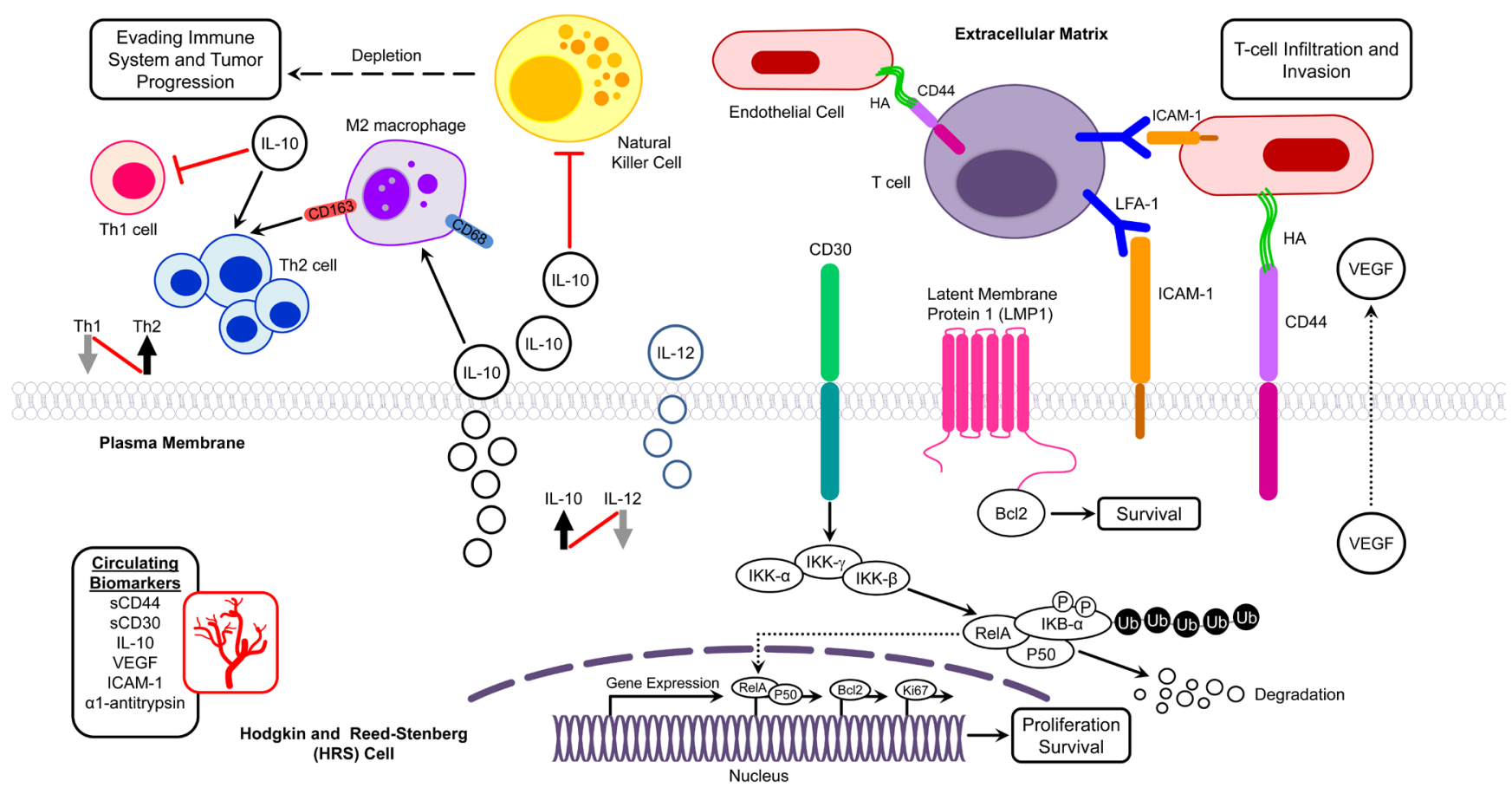

Figure 1: Potential molecular biomarkers in pediatric Hodgkin lymphoma. Interplay of biomarkers in different molecular networks in the tumor microenvironment of Hodgkin lymphoma presenting with infiltration, evasion, and metastasis. Bcl-2, B-cell lymphoma

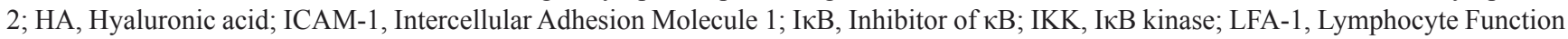
Antigen-1; LMP-1, latent membrane protein 1; Th, T helper; VEGEF, Vascular Growth Endothelial Factor. 


\section{IL-10 and IL-12}

The Th2 cytokine IL-10 is expressed in about 30 $50 \%$ of HL cases. IL-12 is involved in Th1 differentiation and is expressed in primary cHL tumors. IL-10 and IL-12 have antagonistic actions and shifts in Th1/Th2 cytokine ratios to $\mathrm{Th} 2$ predominance are common in cancer patients. (Figure 1). Elevated IL-10 and IL-12 levels in pediatric patients were found to have prognostic significance and were correlated with poor response to therapy, relapse, and shorter EFS and overall survival (OS) (Table 2) [44]. Additionally, IL-10/IL-12 ratios were significantly higher $(p=0.044)$ among symptomatic patients relative to asymptomatic patients, suggesting a role for these cytokines in HL.

\section{CD30}

Overexpression of CD30 results in ligandindependent constitutive signaling that activates the transcription factors $\mathrm{NF}-\mathrm{\kappa B}$ and activator protein-1 (AP-1), which is critical for HRS cell survival (Figure 1) [45]. Under normal physiologic conditions, CD30 is not typically expressed on most human tissues and thus its selective expression on HRS cells makes it an optimal target for directed therapy. The association of high numbers of CD30+ RS cells with poor survival is suggestive of the potential prognostic value of CD30 expression in pediatric HL [46]. The extracellular region of $\mathrm{CD} 30$ is proteolytically cleaved from $\mathrm{CD} 30+$ cells, possibly on activation by $\mathrm{CD} 30 \mathrm{~L}$, to produce a soluble form of $\mathrm{CD} 30, \mathrm{sCD} 30$, which can be detected in the serum. A study by Nadali et al. showed that the presence of $\mathrm{SCD} 30$ in $\mathrm{HL}$ at presentation correlates with several clinical features, including advanced stage, B symptoms, and tumor bulkiness [47]. They also found that $\mathrm{sCD} 30$ serum levels $>100 \mathrm{U} / \mathrm{mL}$ at diagnosis entailed a significantly higher risk of treatment failure [47]. A comparison of low-risk patients (stage I and II) with $\mathrm{sCD} 30<100 \mathrm{U} / \mathrm{mL}$ to those of clinically advanced stage (III and IV) patients with sCD30 levels $\geq 100 \mathrm{U} /$ $\mathrm{mL}$, showed a $42 \%$ decrease in EFS for those patients with higher sCD30 levels $(P<0.001)$ (Table 2$)$. The elevated sCD30 levels in HL reflect the functional behavior of HRS cells, and suggest that $\mathrm{SCD} 30$ may play a pathophysiologic role by mediating interactions between cytokines and the tumor microenvironment.

\section{Intercellular adhesion molecule-1 (ICAM-1, CD54)}

ICAM-1 is involved in the development and progression of the malignant phenotype, and is overexpressed by HRS cells (Figure 1) [48, 49]. Serum
ICAM-1 levels have been found to increase by 2-7 fold in pediatric HL patients, and levels decline or reach normal with complete remission (CR) (Table 2) [50, 51]. High serum ICAM-1 levels are also associated with advanced stages, B symptoms, higher ESR, relapses, and poor outcome [50-52]. Moreover, elevated ICAM-1 levels in patients with advanced stage disease may represent an increased host immune response to tumor cells or simply reflect a larger tumor burden.

\section{CD44}

CD44 is a hyaluronic acid receptor that is involved in tumor development (Figure 1). Elevated serum SCD44 levels in pediatric HL patients are associated with B-symptoms, advanced stages, and poor survival $[53,54]$. Additionally, higher expression levels of CD44 in tumor tissues are correlated with higher serum sCD44 levels, suggesting that at least a part of sCD44 found in $\mathrm{HL}$ patients originated from tumor cells [54].

\section{Alpha-1-antitrypsin (AAT)}

AAT is a systemic inhibitor of neutrophil elastase (NE). An imbalance between AAT and NE may lead to tissue damage that results in tumorigenesis, invasion, and metastasis [55]. Alpha-1-antitrypsin was identified as a biomarker of tumor stage severity using surface enhanced laser desorption/ionization (SELDI-TOF) in 22 pediatric HL patients [56]. A fragment corresponding to $11.7 \mathrm{kDa}$ identified as AAT was expressed to a greater extent in stage IV HL patients than in stage II patients $(P=0.03)$. An observed cluster of peaks was thought to represent allelic variants of AAT, which have been implicated in increased risk of multiple forms of cancer. The role of AAT in HL would benefit from additional analysis.

\section{Natural Killer (NK) cells}

Due to their cytotoxic activity against tumors in vivo, NK cells have been evaluated as prognostic markers in different cancers (Figure 1). In an immunohistochemical analysis of NK cells in 38 pediatric HL patients, a significant decrease in EFS was found among patients with low CD57+ cell counts (NK cells) compared to those with high CD 57+ cell counts [57]. In contrast, another pediatric HL study $(n=17)$ found no correlation between NK cell activity and prognosis [58]. The difference in these results could be attributed to the different detection methods that were used to identify NK cells. 


\section{Nuclear Factor-кB (NF-кB)}

NF- $\kappa \mathrm{B}$ proteins represent a family of inducible transcription factors that includes p65 (RelA), RelB,

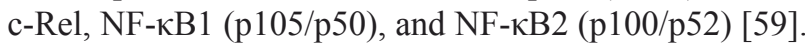
These transcription factors mediate expression of genes involved in the immune response, cell proliferation, tumor metastasis, inflammation, and viral replication. NF- $\mathrm{kB}$ proteins form various homodimers and heterodimers, and are retained in an inactive form by cytoplasmic association with the IкB- $\alpha$ inhibitory protein [59]. Canonical and noncanonical pathways both lead to NF- $\mathrm{KB}$ activation, and both require activation of the IKK complex that consists of catalytic kinase subunits (IKK $\alpha / \operatorname{IKK} \beta)$ and the regulatory scaffold protein IKK $\gamma[60]$.

The canonical NF- $\mathrm{BB}$ pathway is triggered by numerous signals, including those mediated by innate and adaptive immune receptors. Tumor necrosis factor $(\mathrm{TNF}-\alpha)$ activates NF- $\mathrm{kB}$ via canonical phosphorylation of IKK that is mediated by the TNFRSF1A associated via death domain (TRADD), TNF receptor associated factor 2 (TRAF2), and NF-אB inducing kinase (NIK) [61]. When a cell receives a stimulatory signal, IKB- $\alpha$ is phosphorylated

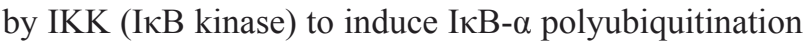
and proteolytic degradation (Figure 1). Following IкBdegradation, NF- $\kappa \mathrm{B}$ dimers translocate into the nucleus to activate gene transcription [62]. In the non-canonical pathway NF-кB2 (p100/RelB) complexes are inactive in the cytoplasm. The non-canonical pathway of NF- $\mathrm{kB}$ activation operates in response to the ligation of only certain TNFR superfamily members. In the non-canonical pathway, TRAF stimulates NIK, which subsequently activates IKK- $\alpha$ that in turn phosphorylates p100 leading to the processing and liberation of the p52/RelB active heterodimer [60].

Dysregulated NF- $\mathrm{KB}$ signaling leads to constitutive $\mathrm{NF}-\kappa \mathrm{B}$ activation, which is common in various lymphoid malignancies, and is a hallmark of HRS cells $[62,63]$. In adult HL patients, studies have reported that NF$\kappa \mathrm{B}$ mutations promote constitutive activity of NF- $\kappa \mathrm{B}$ signaling pathways $[63,64]$, but in pediatric HL, only a few studies have investigated the NF- $\mathrm{BB}$ pathway. The COG clinical trial AHOD0031 that examined intermediate-risk pediatric patient samples $(n=102)$ to clarify the role of NF- $\mathrm{kB}$ pathway proteins in HL found increased protein expression and nuclear localization of proteins in both the classical and alternative NF- $\mathrm{KB}$ pathways in pediatric patients compared to controls [22]. $\mathrm{NF}-\kappa \mathrm{B}$ pathway protein expression was dysregulated in $\mathrm{EBV}+$ tumors and in patients with a slow early response to therapy. Five NF-кB proteins, including nuclear Rel-B, NIK, and A20, along with cytoplasmic Rel-A and IKK- $\beta$, were significantly associated with decreased EFS in multivariate analysis (Table 2). Notably, elevated levels of the non-canonical pathway protein NIK were also associated with a slow response to therapy $(\mathrm{P}=0.005)$
[22]. In a phase II clinical trial of the proteasome inhibitor bortezomib (see below) in combination with ifosfamide/ vinorelbine, nuclear phospho-RelA and RelB NF- $\kappa B$ subunits, as well as cytoplasmic RelB, were overexpressed in all relapsed HL patients compared to either nonmalignant tissue or to HL patients at original diagnosis, but expression of these proteins was not associated with EBV status [65]. These findings suggest that the NF- $\mathrm{KB}$ pathway plays an essential role in pediatric HL high-risk patients.

\section{Heparanase}

Heparanase is an endoglycosidase that cleaves heparan sulfate proteoglycans (HSPG) to alter the structure of the extracellular matrix (ECM), and also plays an important role in tumor metastasis. The prognostic significance of heparanase in pediatric HL patients was demonstrated by a 6 -fold increase in heparanase level at diagnosis and a subsequent decrease associated with complete remission (CR) or a good partial response (Table 2) $[66,67]$. Heparanase levels remained stable in patients with poor treatment response and tumor progression, indicating its association with tumor burden.

\section{Vascular growth endothelial factor (VEGF)}

VEGF is produced by cancer cells, and its activation promotes proliferation and migration of endothelial cells with formation of new blood vessels. High levels of circulating VEGF are a well-established indicator of poor prognosis [68]. Serum VEGF levels have been reported to be elevated by 4-6 fold in pediatric HL patients compared to normal controls $(P<0.0001)$ (Table 2) $[69,70]$. VEGF levels in 9 children correlated with the treatment response assessed after two cycles of chemotherapy, and post-therapy levels were decreased by $50 \%$ in children who were in good partial remission or CR [69]. A similar analysis revealed that the median VEGF concentration in the group with unsuccessful treatment (partial remission, progressive disease, and early relapse) was significantly higher than that in the subgroup of children who achieved $\mathrm{CR}(P=0.02)[70]$. Baseline serum VEGF concentrations among pediatric HL patients thus appear to be a promising predictive marker of response to treatment.

\section{Tumor associated macrophages}

In HL, scant HRS cells ( $1 \%$ of the cell population) are surrounded by a dense microenvironment consisting of a variety of reactive cells ( $99 \%$ of the cell population) that include T cells, B cells, plasma cells, macrophages, mast cells, dendritic cells, neutrophils, eosinophils, and fibroblasts. HRS cells attract infiltrating cells by secreting 
Table 3: Summary of clinical trials in low, intermediate, and high risk pediatric Hodgkin lymphoma

\begin{tabular}{|c|c|c|c|c|c|c|c|c|c|}
\hline Trial Identifier & $\begin{array}{l}\text { Pts. } \\
\text { (n) }\end{array}$ & $\begin{array}{l}\text { Years of } \\
\text { Study }\end{array}$ & Chemotherapy & RT (Gy) & Risk groups & EFS, PFS \% & OS \% & $\begin{array}{l}\text { Toxicity, } \\
\text { patients }(\%)\end{array}$ & Ref \\
\hline \multirow{2}{*}{$\begin{array}{l}\text { NCT00025259/ } \\
\text { AHOD0031 } \\
\text { (III) }\end{array}$} & \multirow{2}{*}{1712} & \multirow{2}{*}{ 2002-2012 } & \multirow{2}{*}{$\mid \begin{array}{lll}4 & \text { ABVE-PC } & \pm \\
2 & \text { DECA (SER } \\
\text { patients) }\end{array}$} & \multirow{2}{*}{$\begin{array}{l}\text { RER: CR no RT; } \\
\text { SER: } 21 \text {, IF }\end{array}$} & \multirow{2}{*}{$\begin{array}{l}\text { Intermediate risk/ } \\
\text { high risk IB, IAE, } \\
\text { IIB, IIAE, IIIA, IVA } \\
\text { bulk/no bulk; IA, IIA } \\
\text { with bulk }\end{array}$} & \begin{tabular}{|l|}
4 yrs $85.0 \quad 4 y r s$ \\
86.9 RER
\end{tabular} & $\begin{array}{l}4 \text { yrs } 97.84 \text { yrs } \\
\text { 98.5 RER }\end{array}$ & \multirow{2}{*}{$\begin{array}{l}\text { hematologic (83.8); } \\
\text { febrile neutropenia } \\
\text { (24.9); RR patients } \\
(14.1) \text {; SMN }(0.8)\end{array}$} & \multirow{2}{*}[102]{} \\
\hline & & & & & & $\begin{array}{l}4 \text { yrs } 77.4 \text { SER (P } \\
<0.001)\end{array}$ & $\begin{array}{l}4 \text { yrs 95.3 SER } \\
(\mathrm{P}<0.001) \\
\end{array}$ & & \\
\hline \multirow{3}{*}{ GPOHHD-95 } & \multirow{3}{*}{1018} & \multirow{3}{*}{ 1995-2001 } & \multirow{3}{*}{ 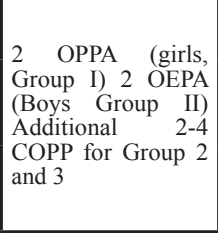 } & \multirow{3}{*}{$\begin{array}{|lr|}\text { CR: No } & \text { RT } 20 \\
>75 \% & \text { tumor } \\
\text { regression } & 30 \\
<75 \% & \text { tumor } \\
\text { regression } & \end{array}$} & $\begin{array}{l}\text { Low Risk (Group I: } \\
\text { IA/B, IIA) }\end{array}$ & 10 yrs PFS 93.2 & 10 yrs 98.8 & \multirow{3}{*}{$\begin{array}{l}\text { RR patients (5.99); } \\
\text { SMN (1.86) }\end{array}$} & \multirow{3}{*}[98]{} \\
\hline & & & & & $\begin{array}{l}\text { Intermediate/high risk } \\
\text { (Group 2: IIB, IIIA, } \\
\text { IAE, IBE, , IIAE) }\end{array}$ & \multirow{2}{*}{10 yrs PFS 85.5} & \multirow{2}{*}{10 yrs 95} & & \\
\hline & & & & & $\begin{array}{ll}\text { high risk } & \text { (Group } \\
\text { 3:IIIB, IV, IIBE, } \\
\text { IIIAE, IIIBE) }\end{array}$ & & & & \\
\hline $\begin{array}{l}\text { NCT00145600/ } \\
\text { HOD99 (II) }\end{array}$ & 88 & $2000-2008$ & 4 VAMP & $\begin{array}{l}\text { CR: no RT; PR: } \\
\text { 25.5, IF }\end{array}$ & low I and II & 2 yrs 90.8 & 2 yrs 100 & Neutropenia (60) & {$[94]$} \\
\hline $\begin{array}{l}\text { NCT00002827/ } \\
\text { P9426 }\end{array}$ & 255 & $1996-2000$ & 2-4 ABVE $\pm \mathrm{DRZ}$ & $25.5, \mathrm{IF}$ & low I, IIA,IIIA & $\begin{array}{l}8 \text { yrs } 86.085 .7 \text { no } \\
\text { DRZ 86.8 } \quad \text { DRZ } \\
(P=0.70)\end{array}$ & 8 yrs 97 & $\begin{array}{l}\text { no DRZ (54); DRZ } \\
\text { (68.8) Neutropenia; } \\
\text { RR patients (11.4); } \\
\text { SMN (1.96) }\end{array}$ & {$[152]$} \\
\hline \multirow{3}{*}{ CCG-5942 } & \multirow{3}{*}{826} & \multirow{3}{*}{ 1995-1998 } & $\begin{array}{l}\text { Group } 1: 4 \mathrm{COPP} / \\
\text { ABV }\end{array}$ & \multirow{3}{*}{$\begin{array}{l}\text { CR: no RT, PR: } \\
21, \mathrm{IF}\end{array}$} & $\begin{array}{l}\begin{array}{l}\text { Low risk (Group 1:I } \\
\text { and II) }\end{array} \\
\end{array}$ & \begin{tabular}{|l|}
10 yrs 89.1 no RT \\
$100 \mathrm{RT}$ \\
\end{tabular} & \multirow{3}{*}{$\begin{array}{l}10 \text { yrs } 95.9 \text { no } \\
\text { RT } 97.1 \text { RT }\end{array}$} & \multirow{3}{*}{$\begin{array}{l}\text { RR patients (13.1); } \\
\text { SMN }(0.36)\end{array}$} & \multirow{3}{*}{ [99] } \\
\hline & & & $\begin{array}{l}\text { Group 2: 6COPP/ } \\
\text { ABV }\end{array}$ & & $\begin{array}{l}\text { Intermediate Risk } \\
\text { (Group 2: I, II, III) }\end{array}$ & \multirow{2}{*}{$\begin{array}{l}10 \text { yrs } 78.95 \text { no RT } \\
86.25 \text { RT }\end{array}$} & & & \\
\hline & & & $\begin{array}{l}\text { Group 3: } 6 \mathrm{COPP} / \\
\text { ABV }\end{array}$ & & $\begin{array}{l}\text { High Risk (Group 3: } \\
\text { IV) }\end{array}$ & & & & \\
\hline $\begin{array}{l}\text { NCT00004010/ } \\
\text { COG-59704 }\end{array}$ & 98 & $1999-2003$ & $\begin{array}{l}4 \text { BEACOPP2 (all } \\
\text { patients), RER: } \\
4 \quad \text { COPP/ABV } \\
\text { (Females), } 2 \text { ABVD } \\
\text { (Males) SER: } 4 \\
\text { BEACOPP2 }\end{array}$ & $\begin{array}{l}\text { RER: Females } \\
\text { no RT, male 21, } \\
\text { IF SER: both } \\
\text { females r and } \\
\text { males 21, IF }\end{array}$ & $\begin{array}{l}\text { High risk IV, II/III } \\
\text { with B symptoms and } \\
\text { bulk }\end{array}$ & 5 yrs 94 & 5 yrs 97 & $\begin{array}{l}\text { Thrombocytopenia } \\
\text { (62); Neutropenia } \\
\text { (83); RR patients } \\
(3.0) \text {; SMN (2.0) }\end{array}$ & {$[105]$} \\
\hline \multirow{3}{*}{$\begin{array}{l}\text { GPOH- } \\
\text { HD-2002 }\end{array}$} & \multirow{3}{*}{573} & \multirow{3}{*}{$2002-2005$} & $\begin{array}{l}2 \text { OEPA (Boys) } 2 \\
\text { OPPA (Girls) } \\
\end{array}$ & CR: no RT & $\begin{array}{l}\text { Low Risk: (Group 1: } \\
\text { IA, IB, IIA) }\end{array}$ & 5 yrs 92.0 & 5 yrs 99.5 & \multirow{3}{*}{$\begin{array}{l}\text { OEPA (70.5)/ OPPA } \\
\text { (52.4) Leukopenia; } \\
\text { OEPA (81.5)/ OPPA } \\
\text { (57.1) Neutropenia; } \\
\text { RR patients (1.74); } \\
\text { SMN (1.9) }\end{array}$} & \multirow{3}{*}{ [93] } \\
\hline & & & $\begin{array}{l}2 \text { OEPA-COPDAC } \\
\text { (Boys) } 2 \text { OPPA- } \\
\text { COPP (Girls) } \\
\end{array}$ & \multirow{2}{*}{$19.8-35$, IF } & $\begin{array}{l}\text { Intermediate Risk: } \\
\text { (Group 2: IE, IIB, } \\
\text { IIAE, IIIA) }\end{array}$ & \multirow{2}{*}{5 yrs 87.7} & \multirow{2}{*}{5 yrs 96.2} & & \\
\hline & & & $\begin{array}{l}4 \text { OEPA-COPDAC } \\
\text { (Boys) 4 OPPA- } \\
\text { COPP (Girls) } \\
\end{array}$ & & $\begin{array}{l}\text { high risk: (Group 3: } \\
\text { IIBE, IIIAE, IIIB, } \\
\text { IVA, IVB, IVE) }\end{array}$ & & & & \\
\hline $\begin{array}{l}\text { NCT00005578/ } \\
\text { P9425 }\end{array}$ & 216 & $1997-2004$ & 5 ABVE-PC DRZ & 21 & $\begin{array}{l}\text { Intermediate Risk: } \\
\text { IB, IIA/IIIA1,IIIA2 } \\
\text { High risk: IIB, IIIB, } \\
\text { IV }\end{array}$ & 5 yrs 84.3 & 5 yrs 95.4 & $\begin{array}{lr}\text { no DRZ } & (29.6 / \\
\text { DRZ } & (72.6) \\
\text { Thrombocytopenia; } \\
\text { no DRZ (77.8)/ DRZ } \\
\text { (93.4) Neutropenia; } \\
\text { no DRZ (0.9), DRZ } \\
(2.8) \text { RR patients } \\
(11.5)\end{array}$ & {$[100]$} \\
\hline
\end{tabular}

ABVD, Doxorubicin, Bleomycin, Vinblastine, and Dacarbazine; ABVE, Doxorubicin, Bleomycin, Vincristine, and Etoposide; BEACOPP, Bleomycin, Etoposide, Doxorubicin, Cyclophosphamide, Vincristine, Procarbazine, Prednisone; COPDAC, Cyclophosphamide, Vincristine, Prednisone, and Dacarbazine; COPP, Cyclophosphamide, Vincristine, Procarbazine, and Prednisone; CR, Complete Remission; DECA, Dexamethasone, Etoposide, Cisplatin, and Cytarabine; DRZ, Dexrazoxane; IF, Involve Field; OEPA, Vincristine, Etoposide, Prednisone, and Doxorubicin; OPPA, Vincristine, Procarbazine, Prednisone, and Doxorubicin; OS, Overall survival; PFS, Progression Free Survival; PR, Partial Remission; RER, Rapid Early Response; RR, Relapsed/Refractory; RT, Radiotherapy; SER, Slow Early Response; SMN, Second Malignant Neoplasm; VAMP, Vinblastine, Doxorubicin, Methotrexate, and Prednisone

cytokines and chemokines that in turn play a role in HRS cell survival, proliferation, and inflammatory reaction [12]. HRS cells also secrete lymphotoxin- $\alpha$ (LT $\alpha)$, which stimulates endothelial cells to upregulate ICAM-1 and hyaluronan levels to enhance recruitment of $\mathrm{T}$ cells into the tumor milieu [71]. Recruitment of infiltrating cells is also stimulated by reactive cells- particularly macrophages and mast cells. In a Th2-shifted immunosuppressive tumor microenvironment, HRS cells are rescued from attack by Th1 cells, which consequently affect HL pathogenesis and prognosis (Figure 1).
The prognostic impact of tumor associated macrophages (TAMs) was assessed by Barros et al. and Gupta et al. in 100 and 96 pediatric HL samples, respectively $[46,72]$. In contrast to the HL study of adult patients by Steidl et al. [73], neither of the two studies found any significant impact of CD68+ macrophages on disease outcome in pediatric populations. In another study, a high number of CD68+ cells in the tumor microenvironment of patients, which may be associated with the presence of EBV, was associated with a good prognosis [74]. However, Barros et al. showed that high 
numbers of CD163+ macrophages were associated with worse progression-free survival in EBV-cases but not in $\mathrm{EBV}+$ cases (Table 2) [72]. These results indicate that the composition of TAMs in the tumor microenvironment is distinct in pediatric HL patients. In $\mathrm{EBV}+$ cases, these macrophages are M1 polarized and therefore may mediate effective immune surveillance [75]. Further studies that use a combination of tumor milieu components in a comparable series of pediatric HL patients may be helpful to understand the role of TAMs in tumor progression and prognosis. The role of EBV and age as potential confounding variables should also be investigated.

A Comparison of the results of biomarker studies in pediatric $\mathrm{HL}$ patients indicates that $\mathrm{NF}-\kappa \mathrm{B}$, sCD30, and ICAM-1, are most likely to be independent prognostic markers for clinical outcome predictions (Table 2), although ICAM-1 requires validation with a larger cohort. A study by Horie et al. [45] revealed that CD30 overexpression in HRS cells results in ligand independent signaling and constitutive NF- $\kappa$ B activation. The study also demonstrated that an adenovirus vector carrying either a decoy CD30 that lacks the cytoplasmic region or a dominant negative $\mathrm{IkB} \alpha$ mutant could block $\mathrm{NF}-\kappa \mathrm{B}$ activation and induce apoptosis. Therefore, therapeutic approaches that focus on blocking CD30 and downregulating $\mathrm{NF}-\kappa \mathrm{B}$ expression could be effective therapeutic approaches for pediatric HL. Assessing levels of a combination of biomarkers such as NF- $\kappa \mathrm{B}, \mathrm{sCD} 30$, and ICAM-1 in pediatric HL patients would be helpful to gain insight into disease progression throughout the course of tumor management. A COG study (NCT01366157/ AHOD11B1) is underway to assess the correlation between human GC-associated lymphoma (HGAL) protein levels and early response in low-risk pediatric HL. A comparison of HGAL protein markers in low-risk and intermediate-risk HL might provide insights into the early transforming events that lead to tumorigenesis.

Other potential biomarkers that have been investigated in adult HL are Thymus and activationregulated chemokine (TARC), Syndecan-1 (SDC1), and Fibroblast growth factor-2 (FGF2). In adult HL, TARC correlates with disease stage, tumor burden, PET positivity, and poorer outcome, which makes it an ideal HL biomarker [76-78]. SDC-1 expression on HRS cells ranges from completely negative to $45 \%-100 \%$ [2, 79, 80]. Increased serum levels or expression of SDC-1 have been associated with poor outcome and adverse prognosis $[81,82]$. Fibroblast growth factor-2 (FGF2) has been shown to be overexpressed in putative circulating CD15+/ CD30+ cells from poor outcome HL patients [81]. The levels of FGF2 and SDC1 were 245- and 91-fold higher, respectively, in the poor outcome group compared to the good outcome group [81]. However, in pediatric patients the prognostic significance of TARC, SDC-1, and FGF2 expression has not been evaluated. Therefore, it may be useful to extrapolate the findings from adult HL patients to pediatric HL patients to help improve clinical management of high-risk patients in particular.

\section{Genetic polymorphism}

Single nucleotide polymorphisms (SNPs) within the promoter regions of cytokine genes have been associated with differential transcription levels, and may have opposing pleiotropic effects in different cancer types. Clinical and pathological features of cHL often result from cytokine imbalances that produce aberrant immune responses. Due to their effects on cytokine expression, cytokine promoter region SNPs are likely mediators of inherited risk. In an analysis of SNPs in various cytokines among 37 pediatric HL patients, the CD14-159 (C>T) SNP was suggested to be associated with pediatric HL [83]. Soluble CD14 (sCD14) is a regulatory molecule that modulates cellular and humoral responses by interacting with T and B cells [84]. Notably, CD14 is located in the same cluster on chromosome $5 \mathrm{q} 31$ as other Th2 cytokines, suggesting that CD14 gene polymorphisms may be involved in regulating Th2-type responses [85]. This possibility highlights the importance of a Th2 biased tumor microenvironment. In another example, a polymorphism in the untranslated region (UTR) of IL-12 (1188 3' UTR $\mathrm{A}>\mathrm{C}$ ) is associated with a significant (2.8-fold) increase in risk in adolescent HL patients [86]. Moreover, IL-12 levels were lower in probands and their unaffected twins compared to controls, suggesting that decreased IL-12 levels are a potential risk factor for HL. Also, germline mutations in IL-2 inducible T cell kinase (ITK) reportedly cause EBV-associated lympho-proliferation. The novel homozygous nonsense mutation $\mathrm{C} 1764 \mathrm{G}$ in ITK exon 16 found in 3 HL patients in a single family was shown to be a potential candidate for a heritable risk factor for EBV-associated HL [87]. Another study identified two heterozygous mutations, C49T and 922delG, in ITK genes in a pediatric patient who presented with B-cell hyperplasia followed by EBV-associated HL [88]. ITK is involved in NK cell maturation and survival, and plays a pivotal role in EBV infection responses. Mutations in the ITK gene lead to production of a truncated protein that produces aberrant immune system responses with severe clinical presentation. Although these findings suggest that ITK mutations may serve as a marker for EBV-associated $\mathrm{HL}$ in pediatric patients, how these mutations influence clinical and histopathological features of pediatric EBV-associated HL is currently under investigation (NCT01490801).

HL survivors are at significant risk for developing secondary malignancies. Two independent genome wide association studies (GWAS) reported that variants at chromosome $6 \mathrm{q} 21$ in pediatric HL patients were associated with radiation induced second malignant neoplasms (SMNs) $[89,90]$. Best and colleagues revealed significant associations between SNPs on chromosome 
6q21, rs4946728 $(P=0.002)$, and rs $1040411(P=0.03)$ and the odds of developing SMNs, which increased by $>3$ fold and $>2$-fold per copy of the major allele rs 4946728 and rs1040411, respectively [89]. These SNPs were also associated with decreased basal expression of the transcriptional repressor PRDM1 (PR domain containing 1, with ZNF domain, also known as BLIMP1) and impaired induction of PRDM1 expression after radiation exposure, suggesting a novel role for PRDM1 as a radiation-responsive tumor suppressor.

The glutathione S-transferase M1 (GSTM1) gene is polymorphic in humans. The frequency of the GSTM1 null genotype is approximately $50 \%$ in the U.S. and Europe. A childhood cancer survivor study (CCSS) of 650 childhood HL survivors in the U.S. and Canada demonstrated that individuals lacking GSTM1 have a significantly higher risk of developing SMN [91]. However, the magnitude of this effect was small, indicating that multiple genes may mediate genetic susceptibility to DNA damage. Therefore, additional studies will be needed to strengthen the associations of these putative risk factors with risk of SMN.

\section{TREATMENT}

The standard chemotherapy regimen of MOPP (nitrogen mustard (mechlorethamine), vincristine, procarbazine and prednisolone) provided high therapeutic success rates in the 1970s. However, two decades later adverse complications became apparent, including risks of secondary malignancy, gonadal toxicity, and sterility in females because of the inclusion of an alkylating agent (mechlorethamine) in this regimen. The combination of ABVD (adriamycin (doxorubicin), bleomycin, vinblastine, and dacarbazine) proved to be more effective than MOPP and had a lower incidence of subsequent leukemia and infertility, and eventually replaced MOPP as the standard of care in the United States. However, ABVD therapy has its own set of complications, including cardiopulmonary toxicity caused by doxorubicin and bleomycin that are subject to the cumulative dose of chemotherapeutic agents and addition of RT. To reduce the risk of longterm toxicities in younger patients, pediatric HL treatment regimens have modified from those used to treat adult HL. Contemporary therapeutic approaches for pediatric HL are based on the refinement of risk group stratification that titrate the length and intensity of chemotherapy, as well as radiation dose using response assessment made through interim or post-chemotherapy PET/CT analysis.

\section{Treatment for favorable-risk pediatric patients}

Various European and North American study groups used ABVD derivatives such as ABVE (doxorubicin, bleomycin, vincristine, etoposide) [92], OEPA (vincristine, etoposide, prednisone, and doxorubicin) for boys, OPPA (vincristine, procarbazine, prednisone, and doxorubicin) for girls [93], and VAMP (vinblastine, doxorubicin, methotrexate, and prednisone) in an effort to limit the toxicities caused by doxorubicin, bleomycin and procarbazine [94]. Based on the response to these contemporary multi-agent chemotherapy regimens, patients could also be optionally treated with low dose (15-30 Gy) involved field radiation (IFRT), which provided an EFS $>90 \%$ and overall survival (OS) $>95 \%$ without significant radiation or alkylator toxicity (Table $3)$. The occurrence of complications from high-dose RT such as cardiovascular disease, second malignancy, hypothyroidism, infertility, and impaired musculoskeletal development in pediatric survivors [95-97] motivated groups to evaluate treatment methods that omit radiation altogether for low-risk patients. Indeed, several clinical trials, evaluating response based chemotherapy by computed tomography, magnetic resonance imaging, gallium scans, and PET scans, demonstrated that radiation therapy may not be needed for low-risk patients who achieve CR after 2 cycles of chemotherapy (Table 3) [94, 98, 99]. The CCG 5942 randomized trial was the first study in children and young adults with HL that evaluated the effect of omitting RT for patients who achieved a complete response to initial COPP/ABV chemotherapy [99]. The long-term outcome of this study showed a 10year EFS rate of $91.2 \%$ for the IFRT group and $82.9 \%$ for the no further therapy group $(P=0.004)$. However, the overall survival probability was similar in both randomization arms $(P=0.50)$ (Table 3$)$. In a study of favorable risk patients, VAMP chemotherapy, which eliminates the alkylating agents, epipodophyllotoxins and bleomycin, resulted in a 5-year EFS of $89 \%$, with no significant difference in outcome between those who were treated with RT (93\%) and those who were not (89\%) $(P$ $=0.61)$, and no patient developed SMNs. However, this finding awaits long-term validation in larger cohorts [94] (Table 3). In the GPOH-HD95 trial [98], the 10-year PFS rates in low-risk patients were not statistically different for the group without RT $(97.0 \%)$ compared to the RT group $(92.2 \%)(P=0.21)$, and the OS rates in all treatment groups were also promising and similar. However, the 10 year PFS rates were unsatisfactory for intermediate and advanced stage disease patients who did not receive RT. The COG trial used Rapid Early Response as a measure of chemosensitivity, which has been a promising predictor of EFS [100]. PET-guided early interim imaging is also a promising approach to reduce treatment-related toxicities among patients undergoing chemotherapy [101, 102]. The results of these studies indicate that reduced RT and modified chemotherapy regimens (cumulative doses of anthracyclines and alkylating agents) produced fewer complications, and are workable strategies to develop balanced treatment protocols through which favorable-risk patients can avoid late sequelae. Of note, the latency and 
Table 4: Summary of completed and ongoing clinical trials involving relapsed/refractory pediatric Hodgkin lymphoma

\begin{tabular}{|c|c|c|c|c|c|c|}
\hline Trial Identifier & Phase, status & Agent (trade name) & Manufacturer & \begin{tabular}{|l} 
Patients \\
(N)
\end{tabular} & Response (\%) & Ref \\
\hline $\begin{array}{l}\text { NCT00070304/ } \\
\text { AHOD0321 }\end{array}$ & II, completed & \begin{tabular}{|l|} 
Gemcitabine (Gemzar), \\
Vinorelbine (Navelbine) \\
\end{tabular} & Eli Lilly & 30 & $\begin{array}{l}76 \%(1 \text { yr EFS } 59.5 \% \text {; } \\
\text { OS } 86.0 \%)\end{array}$ & {$[119]$} \\
\hline $\begin{array}{l}\text { NCT00006760/ } \\
\text { AHOD00P1 }\end{array}$ & II, completed & $\begin{array}{l}\text { Ifosfamide (Ifex), } \\
\text { Vinorelbine (Navelbine) }\end{array}$ & $\begin{array}{l}\text { Bristol-Myers } \\
\text { Squibb; Pierre Fabre } \\
\text { Pharmaceuticals, } \\
\text { Inc. } \\
\end{array}$ & 66 & $\begin{array}{l}72 \%(5 \text { yr EFS } 57.2 \% \text {; } \\
\text { OS } 73.9 \%)\end{array}$ & {$[118]$} \\
\hline NCT00381940 & II, completed & Bortezomib (Velcade) & Millennium & 26 & 83 & {$[65]$} \\
\hline NCT01492088 & \begin{tabular}{|ll}
$\mathrm{I} / \mathrm{II}$, & ongoing/ \\
recruiting & \\
\end{tabular} & \begin{tabular}{|l}
$\begin{array}{l}\text { Brentuximab Vedotin } \\
\text { (Adcetris; SGN-35) }\end{array}$ \\
\end{tabular} & Seattle Genetics & 16 & 64 & {$[153]$} \\
\hline NCT01920932 & II, ongoing/ recruiting & \begin{tabular}{|l}
$\begin{array}{l}\text { Brentuximab Vedotin } \\
\text { (Adcetris; SGN-35) }\end{array}$ \\
\end{tabular} & Seattle Genetics & - & - & \\
\hline NCT02166463 & III, ongoing/recruiting & \begin{tabular}{|l}
$\begin{array}{l}\text { Brentuximab Vedotin } \\
\text { (Adcetris; SGN-35) }\end{array}$ \\
\end{tabular} & Seattle Genetics & - & - & \\
\hline $\begin{array}{l}\text { NCT00994500/ } \\
\text { ADVL0916 }\end{array}$ & I, completed & \begin{tabular}{|ll} 
Vorinostat (Zolinza); \\
Bortezomib (Velcade)
\end{tabular} & Merck & - & - & \\
\hline NCT01321346 & I, completed & \begin{tabular}{|l|}
$\begin{array}{l}\text { Panobinostat/LBH-589 } \\
\text { (Farydak) }\end{array}$ \\
\end{tabular} & Novartis & - & - & \\
\hline NCT01748721 & I, completed & $\begin{array}{l}\text { MORAb-004 } \\
\text { (Ontuxizumab) }\end{array}$ & Morphotek & - & - & \\
\hline NCT02304458 & $\begin{array}{l}\mathrm{I} / \mathrm{II}, \quad \text { ongoing/ } \\
\text { recruiting }\end{array}$ & Nivolumab & $\begin{array}{l}\text { Bristol-Myers } \\
\text { Squibb }\end{array}$ & - & - & \\
\hline
\end{tabular}

EFS, Event Free Survival; HDAC, Histone Deacetylase; NF-kB, Nuclear Factor Kappa-light-chain-enhancer of Activated B Cells; OS, Overall Survival; PD-L1, Programmed Death-ligand 1; TEM1, Tumor Endothelial Marker 1

frequency of secondary tumors is comparable in children treated with low dose (15-25 Gy) and high-dose IFRT [103]. Taken together, these findings appear to justify the omission of RT in early stage pediatric HL patients.

\section{Treatment for intermediate/high-risk pediatric patients}

Many pediatric oncology groups consider that the combined chemotherapy and RT modality for highrisk patients is superior to chemotherapy-only protocols as a means to avoid reaching the toxicity threshold for high cumulative doses of alkylating agents, bleomycin, and anthracyclines, as well as to reduce relapses and subsequent need for toxic salvage therapy. Adjuvant RT has been demonstrated to be effective in many clinical trials for pediatric high-risk HL patients. The Stanford/St. Jude/Dana Farber consortium investigated VAMP/COP and response-based IFRT for high-risk HL patients [104]. The poor outcomes of the study indicated that limited cumulative doses of alkylating agents and anthracycline chemotherapy in combination with low-dose IFRT are not sufficient for disease control in high-risk patients. The incorporation of dose-intensification strategies such as BEACOPP (bleomycin, etoposide, doxorubicin, cyclophosphamide, procarbazine, and prednisone) [105] and ABVE-PC [102] (doxorubicin, bleomycin, vincristine, etoposide, prednisone, and cyclophosphamide) in intermediate/high-risk patients have shown promising outcomes, although BEACOPP has not been widely used because of its various toxicities (e.g., hematologic toxicity, cardiopulmonary toxicity, secondary malignancy, and infertility) (Table 3). However, an escalated BEACOPP regimen in adult HL patients was recently evaluated using PET-guided interim response assessment to identify poor outcome patients and direct subsequent treatment modifications [106]. In this study, all patients received two cycles of escalated BEACOPP, then underwent PET imaging. In the PET arm, patients who were PET-positive received four additional cycles of escalated BEACOPP and PET-negative patients received four cycles of ABVD. In the standard arm, patients received 6 cycles of escalated BEACOPP regardless of PET status. The estimated 2-year PFS was similar in both groups: $91.6 \%$ in the standard arm and $88.3 \%$ in the PET-driven arm $(p=0.79)$. Future studies will be needed to examine the feasibility of this strategy for pediatric patients with PET-positive advanced stage HL. The ABVE-PC regimen excludes procarbazine and limits the cumulative dose of epipodophyllotoxins and anthracyclines, thereby lowering the number of SMNs $(0.8 \%)$ [102]. This regimen was used in a COG trial where it showed excellent 4 year EFS (85\%) and OS (98\%), although the relapse rate was $14 \%$ (Table 3). Pediatric Oncology Group used this dose-dense regimen in its P9425 trial with or without dexrazoxane (topoisomerase inhibitor), as a cardioprotectant to prevent anthracyclineassociated cardiac toxicity during treatment. The study in advanced HL patients proved to be effective in disease control with a 5 -year EFS of $84 \%$ and OS of $95 \%$, however dexrazoxane could possibly be associated with increased risk of second malignancies and acute myeloid 
Table 5: Secondary leukemia frequency, incidence, mortality rate in pediatric Hodgkin lymphoma

\begin{tabular}{|c|c|c|c|c|c|c|c|c|c|}
\hline $\begin{array}{l}\text { Patients } \\
\text { (N) }\end{array}$ & \begin{tabular}{|l|} 
Patients \\
with SMN/ \\
SMN no. \\
$(\%)$
\end{tabular} & $\begin{array}{l}\text { Patients with } \\
\text { leukemia (n) }\end{array}$ & $\begin{array}{l}\% \\
\text { leukemia } \\
\text { of total } \\
\text { SMNs }\end{array}$ & $\begin{array}{l}\text { Mean/ } \\
\text { Median } \\
\text { latency } \\
\text { (leukemia) } \\
\text { (yrs.) }\end{array}$ & $\begin{array}{l}\text { Primary } \\
\text { HL } \\
\text { diagnosis } \\
\text { period }\end{array}$ & $\begin{array}{l}\text { CI of leukemia } \\
\text { at } 30 \text { yrs. unless } \\
\text { specified }\end{array}$ & $\begin{array}{l}\text { SIR } \\
\text { (Leukemia) }\end{array}$ & $\begin{array}{l}\text { Mortality } \\
\text { (leukemia) } \\
\text { n (\%) }\end{array}$ & Ref \\
\hline 2548 & $147(5.8)$ & \begin{tabular}{|l|}
7 (5 AML, 1 ALL, \\
1 CML) \\
\end{tabular} & 4.76 & 5.3 & 1978-2002 & $1.5^{*}$ & 10.4 & $6(85 \%)$ & [145] \\
\hline 110 & $18(16.3)$ & 4 (3 AML, 1 ALL) & 22.2 & 6.9 & $1970-90$ & 4 (15 yrs plateau) & 90.9 & $4(100 \%)$ & [103] \\
\hline 930 & $102(11)$ & 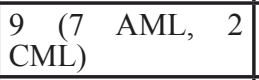 & 8.82 & 6.4 & $1960-90$ & - & 21.49 & $9(100 \%)$ & [154] \\
\hline 1380 & $73(5.3)$ & 27 & 36.9 & 4.3 & $1955-86$ & 2.1 & 174.8 & $25(93 \%)$ & [139] \\
\hline 2739 & $195(7.1)$ & 26 & 13.3 & 6.6 & 1935-94 & - & 33.3 & - & [140] \\
\hline 182 & $28(15.3)$ & \begin{tabular}{|l}
2 (1 AML, 1 \\
erythroleukemia)
\end{tabular} & 7.1 & 10.68 & 1960-89 & 1.98 & 21.96 & - & [155] \\
\hline 694 & $59(8.5)$ & 8 (7 AML) & 13.55 & 4.3 & $1960-95$ & - & - & $8(100 \%)$ & [156] \\
\hline 1380 & $79(5.7)$ & $\begin{array}{l}26 \text { (24 AML, } 1 \\
\text { ALL, 1 CML })\end{array}$ & 32.9 & 4.4 & $1955-86$ & $\begin{array}{lll}2.8 \quad(15 & \text { yrs } \\
\text { plateau })\end{array}$ & 99.6 & $25(96 \%)$ & [157] \\
\hline 1641 & $62(3.8)$ & 7 & 11.29 & - & $1943-87$ & 0.8 & 17 & - & [158] \\
\hline
\end{tabular}

ALL, Acute Lymphocytic Leukemia; AML, Acute Myeloid Leukemia; CI, Cumulative Incidence; CML, Chronic Myeloid Leukemia; SIR, Standardized Incidence Ratio; SMN, Second Malignant Neoplasm

* Cumulative incidence for leukemia and NHL together

leukemia (AML)/myelodysplastic syndrome when used with ABVE-PC regimen [107]. The study evaluating long-term effects of dexrazoxane on secondary cancer and cardiac health among childhood HL survivors is needed to validate these results. In the GPOH-HD-2002 trial, genderstratified chemotherapy with OEPA-COPDAC for boys and OPPA-COPP for girls was used to treat intermediate and advanced stage HL patients. In this trial, procarbazine in COPP was replaced by dacarbazine, which has reduced gonadotoxicity and has seen wide use in ABVD regimens. Response based IFRT was an integral part of the treatment for high-risk groups, even in patients who achieved CR after chemotherapy. The trial showed 5-year EFS of $89 \%$ and OS of $97.4 \%$ with SMNs occurring in $~ 2 \%$ of cases. Both regimens were found to be interchangeable among male and female pediatric patients with intermediate and advanced stage cHL (Table 3) [93]. The Euronet trial (NCT00433459) is currently underway to compare the efficacy OEPA-COPDAC and OEPA-COPP treatments using PET-guided response assessment after two cycles of chemotherapy. In light of these clinical trial results, the challenge is to prevent relapse in early stage patients who did not receive RT and to limit the dose of alkylating agents and RT to minimize the incidence of SMNs.

\section{Salvage therapy for relapsed/refractory (RR) pediatric patients}

Although there has been remarkable progress in the treatment of pediatric HL that resulted in high cure rates, $10-25 \%$ of cases are relapse/refractory (RR) patients, which present greater challenges for clinical management. There is currently no gold standard for second line treatment, but the retrieval regimen for RR patients includes re-induction or salvage chemotherapy and, thereafter, high dose chemotherapy (HDCT) followed by autologous stem cell transplantation (ASCT). This regimen is associated with remission rates of approximately 50-65\% [108, 109]. However, lowrisk patients with late relapse and limited stage may be retrieved with standard dose chemotherapy (SDCT) and RT. The most common prognostic factors are chemosensitivity to initial salvage therapy [110], primary progressive disease $[111,112]$, time to relapse [113], and extranodal disease [114]. As with adult patients, pediatric patients also show poor prognosis, associated with time from diagnosis to first relapse of $<1$ year [115]. Likewise, primary progressive HL that remains refractory has a poor outcome with HDCT/ASCT in children. Therefore, alternative treatment approaches, including allogeneic stem cell transplant (alloSCT) or novel biological and targeted therapies, should be considered for these patients. In recent years, patients were more often retrieved with mini-BEAM [BCNU (carmustine), etoposide, cytarabine, melphalan] (BEAM chemotherapy in lower doses) [116]; MINE (mitoguazone, ifosfamide, vinorelbine, and etoposide) [113], or alternating IEP-ABVD (ifosfamide, etoposide, prednisolone) [109]. Reinduction regimen, ICE (Ifosfamide, carboplatin, and etoposide) in RR pediatric and adult patients has shown a combined response rate of $88 \%$ [117]. However, ICE poses a risk for 
myelosuppression and secondary malignancy because of alkylating agents and epipodophyllotoxins. Contemporary non-etoposide retrieval regimens in RR patients, such as the combination of ifosfamide with vinorelbine (IV) [118] or gemcitabine in combination with vinorelbine (GV) [119] resulted in overall response rates of $72-76 \%$ (Table 4). However, pediatric patients with early relapse or inadequate response rate are unlikely to achieve long-term remission with standard salvage therapy, and their survival remains very poor, ranging from 18-41\% [109, 110, 115]. This low survival rate presents a therapeutic challenge for treating RR patients, and reinforces the need to test novel immune and non-immune strategies to combat HL.

\section{Targeted therapies}

Due to the limited success rates of HDCT with ASCT, and the association of these regimens with significant risk of secondary malignancies, there is a need to develop alternative therapeutic approaches that are efficacious and safe for RR pediatric patients. Novel therapeutic approaches include the use of monoclonal antibodies, signal transduction inhibitors, immunotherapy, epigenetic agents such as histone deacetylase (HDAC) inhibitors and demethylating agents, and agents that target the tumor microenvironment [120]. Unfortunately, randomized clinical trials of these approaches have not yet been conducted in pediatric patients.

Brentuximab vedotin (Bv) (SGN-35) is an antiCD30 antibody-drug conjugate that delivers the antitubulin agent monomethyl auristatin E (MMAE) to HRS cells where it binds tubulin to disrupt the microtubule network and induce apoptosis [121] (Figure 2). Compared to standard salvage regimens, $\mathrm{Bv}$ alone (as a primary salvage chemotherapy) or combined with standard therapy (as a first line therapy in treatment-naive patients) produced better outcomes (ORR 65\%) and reduced toxicity in RR patients $[122,123]$. In a phase I/II trial, 16 pediatric patients with RR HL were treated with $\mathrm{BV}$ to achieve ORR (CR+ PR) of $64 \%$ and $21 \% \mathrm{CR}$. These preliminary treatment results provide hope that $\mathrm{BV}$ treatment may also benefit RR pediatric HL patients. Using the same guidelines as for adult patients, several contemporary pediatric clinical trials are underway to test the effectiveness of $\mathrm{Bv}$ as a front-line treatment: i) $\mathrm{Bv}$ substituting for vincristine in the OEPA/COPDAC regimen (NCT01920932); ii) Bv in combination with AVEPC or ABVE-PC alone (NCT02166463/AHOD1331 (Table 4). Also, the combination of Bv with gemcitabine is being assessed in a phase $1 / 2$ trial for RR pediatric and young adult HL (NCT01780662/AHOD1221). The

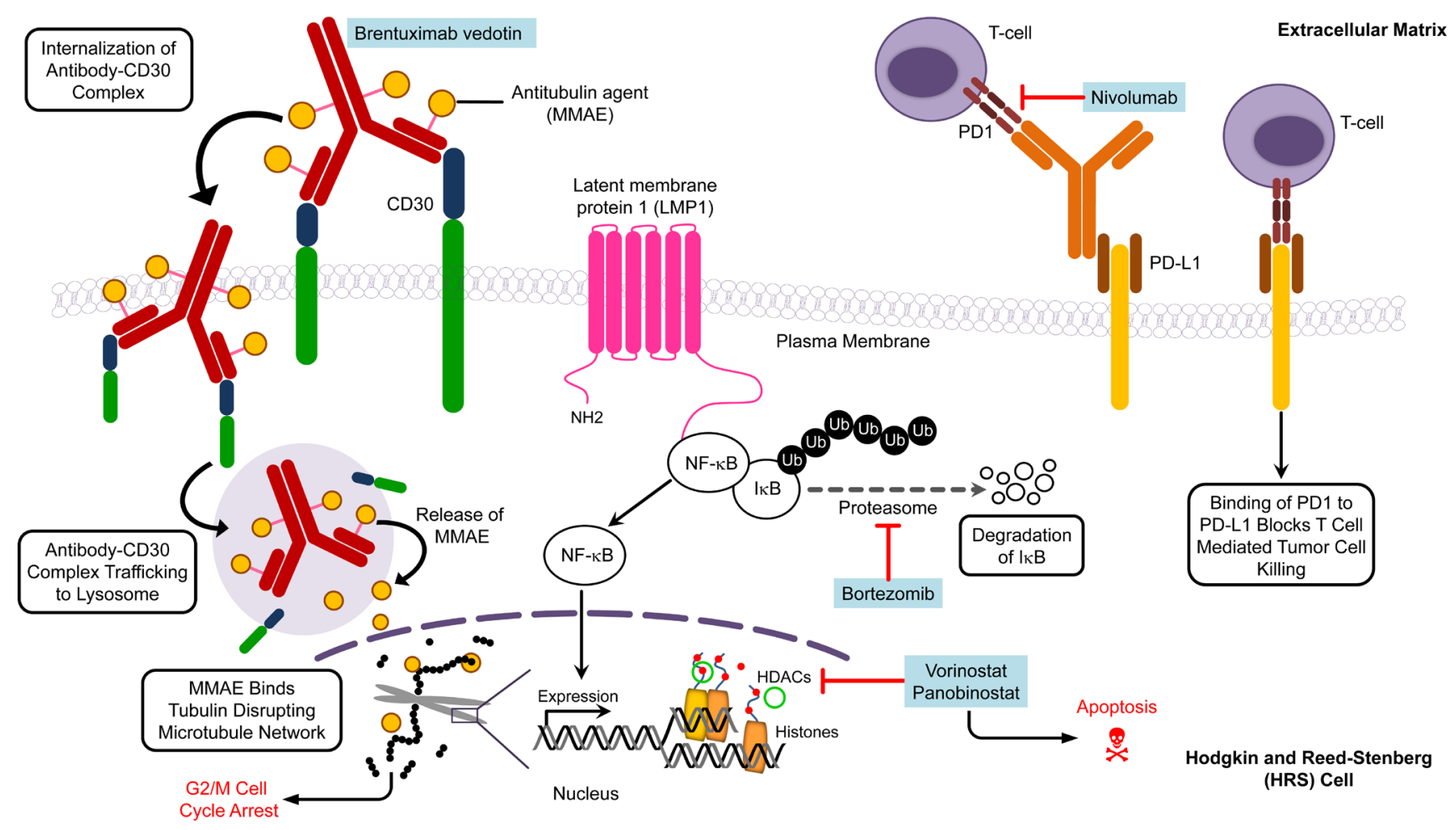

Figure 2: Molecular targets and agents affecting specific targets in pediatric Hodgkin lymphoma. Multiple pathways are implicated in Hodgkin lymphoma and thus present potential targets for therapy. The various targets and agents illustrate the need for future clinical trials to focus on synergistic action of inhibitors to kill tumor cells. The drugs are listed in blue boxes adjacent to the corresponding target. HDAC, histone deacetylase; MMAE, monomethyl auristatin E; PD1, programmed cell death protein 1; PD-L1, programmed deathligand 1. 
objective of these approaches is to reduce toxicity by using a combination of agents that have distinct mechanisms of action against tumor cells.

Proteasome inhibitors have been used to treat HL based on their ability to block degradation of I $\kappa \mathrm{B} \alpha$ that in turn inhibits NF-кB activation. Bortezomib (Velcade, PS341) selectively inhibits the 26S proteasome to stabilize proteins that are degraded by the ubiquitin-proteasome

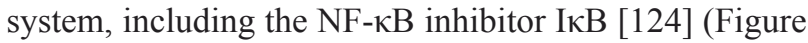
2). The results from a phase 2 clinical trial (AHOD0521) investigating the tolerability and efficacy of bortezomib in combination with ifosfamide and vinorelbine (IV) in 23 evaluable RR pediatric HL patients demonstrated an ORR approaching $83 \%$, which is a marked improvement over the poor response seen with this combination in adult $\mathrm{HL}$ patients (Table 4) [65, 125].

To date, $\mathrm{Bv}$ and bortezomib have been shown to be the most effective agents to treat RR pediatric patients (Table 4) and highlights the essential role of the CD30 and NF- $\mathrm{KB}$ biomarkers in HL. The combination of $\mathrm{Bv}$ and Bortezomib may exert a synergistic cytotoxic effect that promotes downregulation of NF- $\mathrm{KB}$ expression (see Biomarkers section), and may represent a novel therapeutic approach to improve CD30-based targeted therapy. Moreover, an in vitro and xenograft model study revealed the synergistic cytotoxic effect of 5F11 (antiCD30 mAb) and bortezomib in HRS cells, which again emphasizes the importance of CD30 in particular as a $\mathrm{HL}$ biomarker [126].

The HDAC inhibitors vorinostat and panobinostat have favorable antiproliferative activity that is manifested through cell cycle arrest and apoptosis (Figure 2). Interestingly, the anti-tumor activity of vorinostat is associated with decreased production of Th2 cytokines and chemokines, including TARC, that confers immunosuppression and protects tumor cells from cytotoxic $\mathrm{T}$ cells [127]. Therefore, vorinostat may sufficiently alter the tumor microenvironment to restore the Th1 anti-tumor response, and consequently suppress tumor progression and metastasis in HL patients. Panobinostat also inhibits T cell PD-1 expression in HL cell lines and RR HL patients, suggesting that this agent may promote tumor cell recognition and elimination by effector lymphocytes [128]. However, the clinical use of vorinostat and panobinostat as single agents has been of limited value in adult HL patients, and produced response rates of only $4 \%$ [129] and $27 \%$ [130], respectively. Thus, contemporary clinical trials are exploring their use in combination with other standard salvage agents in RR pediatric HL patients (NCT00994500; NCT01321346). HDAC inhibitors have been shown to interact synergistically with proteasome inhibitors to induce apoptosis [131], and studies are also underway to evaluate these findings in patients (Table 4) since combination therapies involving HDAC inhibitors and proteasome inhibitors may provide meaningful clinical outcomes.
Ontuxizumab (MORAb-004) is a recently developed humanized recombinant mouse antibody $(\mathrm{Ab})$ directed against endosialin (TEM-1, CD248) [132], which is predominantly expressed on the surface of cells with a mesenchymal origin, including tumor vasculature, tumor pericytes, and active tumor stromal fibroblasts $[133,134]$. Inhibiting endosialin by monoclonal $\mathrm{Ab}$ can decrease tumor growth and tumor metastasis [135]. As such, clinical trials aimed to determine safety profiles and the optimal dose for endosialin-targeted drugs are underway in RR pediatric HL patients (NCT01748721).

Nivolumab (BMS-936558) is a monoclonal antibody that may block the PD-1 receptor expressed on peritumoral T cells. Programmed death-ligand 1 (PD-L1) is aberrantly expressed on HRS cells and interacts with PD-1 to contribute to evasion of immune detection by inhibiting $\mathrm{T}$ cell receptor signaling (Figure 2). Promising results from an early study in adult patients [136] prompted further investigation of nivolumab in RR pediatric HL patients (NCT02304458).

\section{SECOND MALIGNANT NEOPLASMS (SMNs) - FOCUS ON SECONDARY LEUKEMIA}

SMNs have long been known to be a major complication in long-term survivors of HL. SMNs have a serious impact, particularly in children who, at the time of treatment, are still in the growth phase and thus are more sensitive to mutagenic compounds and radiations than adults [137, 138]. Among all childhood cancer survivors, HL survivors exhibit the highest risk for SMNs, with an absolute SMN excess of 5 to 8 per 1,000 person years of follow-up [139-141]. HL survivors are at increased risk for developing secondary sarcomas and carcinomas including breast, thyroid, gastrointestinal, lung, and nonHodgkin lymphoma (NHL) caused by RT that can occur 10-20 years after HL therapy [139, 140]. HL survivors are also more susceptible to secondary leukemia that is attributed to alkylating agents (mechlorethamine and procarbazine) or epipodophyllotoxin (topoisomerase II inhibitor- etoposide) [142].

Table 5 lists the cumulative incidences, SIR values, and mortality rates for secondary leukemia among childhood HL survivors. Notably, up to $37 \%$ of secondary malignancies that occur after HL treatment are leukemias, and of these, $70-90 \%$ are AML (Table 5). In CCSS, secondary AML affected $1.8 \%$ of HL patients, but only those cases who survived at least 5 years after primary cancer diagnosis, while leukemia can emerge as early as 2 years after HL treatment [141]. The overall cumulative incidence of secondary leukemia up to 30 years after treatment for childhood HL ranges from $0.8 \%$ to $2.1 \%$, depending on the therapy (Table 5). The risk of developing leukemia peaks at 4 to 6 years of follow-up, declines over the next 10 years, and then plateaus at around 15- 
20 years $[139,140]$. However, the latency period between initiating treatment with topoisomerase II inhibitors and leukemia onset is even shorter, with a median of 2 to 3 years [143]. The risk of developing secondary leukemia, including AML, following childhood treatment for $\mathrm{HL}$ is 10.4- to 174.8 -fold greater than the risk for the general pediatric population (Table 5). However, variability in cohort size, patient classification, treatment approach, and duration of follow-up complicates the comparison of these studies. Dorffel et al. reported relatively lower standardized incidence ratio (SIR) value for secondary leukemia apparently because none of the patients in this cohort were given the alkylating agent mechlorethamine in chemotherapeutic DAL/GPOH protocols for HL (Table 5) $[144,145]$. Dose intense chemotherapy [105] or ASCT [146] elevates the risk of secondary leukemias, thus the incidence of secondary leukemia is higher in relapsed patients who require prolonged maintenance treatment with multiple courses of combination chemotherapy and transplantation.

The prognosis of secondary leukemia is significantly poorer compared to other hematological malignancies with a median survival of 2.5 to 4.5 months after diagnosis, and mortality rates that often reach $100 \%$ (Table 5). The OS and EFS at 3 years, specifically for therapy-related myelodysplastic syndrome/acute myeloid leukemia (tMDS/AML) secondary to primary cancers, are about $50 \%$ lower than that for de novo AML/MDS [147]. An increased risk of tMDS/AML is associated with mutations in genes that encode detoxifying enzymes (e.g., GSTM1, GSST1, and GSTP1), drug metabolizing enzymes (cP450), and proteins involved in DNA repair and apoptosis (XRCC1, p53) [91] (see section on genetic polymorphisms). In addition to genetic factors and chemotherapeutic agents, other unknown factors are likely involved in the development of secondary AML, as suggested by the occurrence of leukemias in seven HL patients who had not received mechlorethamine or etoposide [145]. In this regard, FGFR1 overexpression has been observed in lymph node biopsies of HL patients who developed AML [148]. Thus, assessment of FGFR as a potential molecular marker in pediatric HL patients who develop leukemia would be of value. Moreover, FGF2 can be overexpressed in adult HL patients [81], which highlights the importance of this signaling pathway, particularly in high-risk patients who are more likely to develop secondary AML.

Although recent successes in treating HL have been nothing short of revolutionary, we should not overlook the incidence of SMNs. Importantly, clinicians should comprehensively evaluate risks and benefits of available therapeutic approaches, and patients must be educated about the trade-offs between different treatment regimens and the importance of follow-up. Additionally, less aggressive regimens with low oncogenic potential that involve targeted therapies and lower doses of radiation should be given serious consideration when selecting HL treatment regimens. Genetic screening for potential SNPs that are implicated in HL may also offer progress toward personalized treatments for $\mathrm{HL}$.

\section{CONCLUDING REMARKS}

Most pediatric HL patients are cured with current first line risk-adapted and response-based chemotherapy. This high cure rate represents a success in the treatment of childhood cancer. Despite the high overall cure rates for HL patients, patients with early relapse or inadequate response are unlikely to achieve long-term remission with standard salvage therapy, and their prognosis remains grim. Therefore, identification of novel therapeutic targets to improve outcomes in this group remains an important challenge. The primary long-term complication of HL treatment is the development of secondary malignancy, which remains a cause for concern, especially for pediatric HL patients. As a means to avoid future side effects, recent clinical trials examined the effect of omitting RT in early stage patients. Although therapeutic sequelae and genetic factors are important in the development of secondary malignancies, other factors are involved, and, therefore, further studies are needed to identify biomarkers that indicate high-risk patients who will likely experience poor outcomes and are predisposed to develop secondary malignancies. We also need to understand the underlying mechanisms that are involved in the pathophysiology of high-risk HL and incorporate novel agents that can be personalized to achieve an initial cure and minimize late effects of HL therapy.

\section{ACKNOWLEDGEMENTS}

The authors thank V. Desai for helping with reference organization, and J. Nagpal for helpful discussions. This work was supported by grants from the Lisa B. Fishman Foundation and The John Theurer Cancer Center of Hackensack University Medical Center.

\section{CONFLICTS OF INTEREST}

The authors declare no conflicts of interest.

\section{REFERENCES}

1. Kuppers R, Rajewsky K, Zhao M, Simons G, Laumann R, Fischer R and Hansmann ML. Hodgkin disease: Hodgkin and Reed-Sternberg cells picked from histological sections show clonal immunoglobulin gene rearrangements and appear to be derived from B cells at various stages of development. Proc Natl Acad Sci U S A. 1994; 91:1096210966.

2. Bräuninger A, Wacker HH, Rajewsky K, Küppers R and 
Hansmann ML. Typing the histogenetic origin of the tumor cells of lymphocyte-rich classical Hodgkin's lymphoma in relation to tumor cells of classical and lymphocytepredominance Hodgkin's lymphoma. Cancer Res. 2003; 63:1644-1651.

3. Kanzler H, Kuppers R, Hansmann ML and Rajewsky K. Hodgkin and Reed-Sternberg cells in Hodgkin's disease represent the outgrowth of a dominant tumor clone derived from (crippled) germinal center B cells. The Journal of experimental medicine. 1996; 184:1495-1505.

4. Kuppers R, Schwering I, Brauninger A, Rajewsky K and Hansmann ML. Biology of Hodgkin's lymphoma. Ann Oncol. 2002; 13 Suppl 1:11-18.

5. Schwering I, Brauninger A, Klein U, Jungnickel B, Tinguely M, Diehl V, Hansmann ML, Dalla-Favera R, Rajewsky K and Kuppers R. Loss of the B-lineage-specific gene expression program in Hodgkin and Reed-Sternberg cells of Hodgkin lymphoma. Blood. 2003; 101:1505-1512.

6. Stein H, Marafioti T, Foss HD, Laumen H, Hummel M, Anagnostopoulos I, Wirth T, Demel G and Falini B. Downregulation of BOB.1/OBF.1 and Oct2 in classical Hodgkin disease but not in lymphocyte predominant Hodgkin disease correlates with immunoglobulin transcription. Blood. 2001; 97:496-501.

7. Tzankov A, Zimpfer A, Pehrs AC, Lugli A, Went P, Maurer R, Pileri S and Dirnhofer S. Expression of B-cell markers in classical hodgkin lymphoma: a tissue microarray analysis of 330 cases. Mod Pathol. 2003; 16:1141-1147.

8. Muschen M, Rajewsky K, Brauninger A, Baur AS, Oudejans JJ, Roers A, Hansmann ML and Kuppers R. Rare occurrence of classical Hodgkin's disease as a T cell lymphoma. The Journal of experimental medicine. 2000; 191:387-394.

9. Pinkus GS, Pinkus JL, Langhoff E, Matsumura F, Yamashiro S, Mosialos G and Said JW. Fascin, a sensitive new marker for Reed-Sternberg cells of hodgkin's disease. Evidence for a dendritic or B cell derivation? The American journal of pathology. 1997; 150:543-562.

10. Tzankov A, Bourgau C, Kaiser A, Zimpfer A, Maurer R, Pileri SA, Went P and Dirnhofer S. Rare expression of T-cell markers in classical Hodgkin's lymphoma. Mod Pathol. 2005; 18:1542-1549.

11. Venkataraman G, Song JY, Tzankov A, Dirnhofer S, Heinze G, Kohl M, Traverse-Glehen A, Eberle FC, Hanson JC, Raffeld MA, Pittaluga S and Jaffe ES. Aberrant T-cell antigen expression in classical Hodgkin lymphoma is associated with decreased event-free survival and overall survival. Blood. 2013; 121:1795-1804.

12. Küppers R. Molecular biology of Hodgkin lymphoma. Hematology Am Soc Hematol Educ Program. 2009:491496.

13. Howlader N NA, Krapcho M, Garshell J, Miller D, Altekruse SF, Kosary CL, Yu M, Ruhl J, Tatalovich Z, Mariotto A, Lewis DR, Chen HS et al. (1975-2012). SEER
Cancer Statistics Review. (National Cancer Institute. Bethesda, MD).

14. Foltz LM, Song KW and Connors JM. Hodgkin's lymphoma in adolescents. J Clin Oncol. 2006; 24:25202526.

15. Barista I, Varan A and Ozyar E. Bimodal age distribution in Hodgkin's disease and nasopharyngeal carcinoma. Med Hypotheses. 2007; 68:1421.

16. Bazzeh F, Rihani R, Howard S and Sultan I. Comparing adult and pediatric Hodgkin lymphoma in the Surveillance, Epidemiology and End Results Program, 1988-2005: an analysis of 21734 cases. Leukemia \& lymphoma. 2010; 51:2198-2207.

17. Naresh KN, Johnson J, Srinivas V, Soman CS, Saikia T, Advani SH, Badwe RA, Dinshaw KA, Muckaden M, Magrath I and Bhatia K. Epstein-Barr virus association in classical Hodgkin's disease provides survival advantage to patients and correlates with higher expression of proliferation markers in Reed-Sternberg cells. Ann Oncol. 2000; 11:91-96.

18. Kilger E, Kieser A, Baumann $M$ and Hammerschmidt W. Epstein-Barr virus-mediated B-cell proliferation is dependent upon latent membrane protein 1, which simulates an activated CD40 receptor. EMBO J. 1998; 17:1700-1709.

19. Caldwell RG, Wilson JB, Anderson SJ and Longnecker R. Epstein-Barr virus LMP2A drives B cell development and survival in the absence of normal B cell receptor signals. Immunity. 1998; 9:405-411.

20. Axdorph U, Porwit-MacDonald A, Sjoberg J, Grimfors G, Ekman M, Wang W, Biberfeld P and Bjorkholm M. Epstein-Barr virus expression in Hodgkin's disease in relation to patient characteristics, serum factors and blood lymphocyte function. Br J Cancer. 1999; 81:1182-1187.

21. Weiss LM, Movahed LA, Warnke RA and Sklar J. Detection of Epstein-Barr viral genomes in Reed-Sternberg cells of Hodgkin's disease. N Engl J Med. 1989; 320:502506.

22. Horton TM, Sheehan AM, Lopez-Terrada D, Hutchison RE, Narendra S, Wu MF and Liu H. Analysis of NF- B pathway proteins in pediatric Hodgkin lymphoma: Correlations with EBV status and clinical outcome - A Children's Oncology Group study. Lymphoma. 2012; 2012 (no pagination) (341629).

23. Schmitz R, Hansmann ML, Bohle V, Martin-Subero JI, Hartmann S, Mechtersheimer G, Klapper W, Vater I, Giefing M, Gesk S, Stanelle J, Siebert R and Küppers R. TNFAIP3 (A20) is a tumor suppressor gene in Hodgkin lymphoma and primary mediastinal B cell lymphoma. The Journal of experimental medicine. 2009; 206:981-989.

24. Akta S, Kargi A, Olgun N, Diniz G, Erbay A and Vergin C. Prognostic significance of cell proliferation and apoptosisregulating proteins in Epstein-Barr virus positive and negative pediatric Hodgkin lymphoma. Lymphat Res Biol. 2007; 5:175-182. 
25. Cainap S, Rachisan A, Fetica B, Cosnarovici R, Mihut E, Popa G, Gheban D and Cainap C. EBV in pediatric neoplasia - intensity of infection as independent prognostic factor. Journal of medicine and life. 2012; 5:283-287.

26. Claviez A, Tiemann M, Lüders H, Krams M, Parwaresch R, Schellong $\mathrm{G}$ and Dörffel W. Impact of latent Epstein-Barr virus infection on outcome in children and adolescents with Hodgkin's lymphoma. J Clin Oncol. 2005; 23:4048-4056.

27. Chabay PA, Barros MH, Hassan R, De Matteo E, Rey G, Carrico MK, Renault IZ and Preciado MV. Pediatric Hodgkin lymphoma in 2 South American series: a distinctive epidemiologic pattern and lack of association of Epstein-Barr virus with clinical outcome. J Pediatr Hematol Oncol. 2008; 30:285-291.

28. Engel M, Essop MF, Close P, Hartley P, Pallesen G and Sinclair-Smith C. Improved prognosis of Epstein-Barr virus associated childhood Hodgkin's lymphoma: study of 47 South African cases. J Clin Pathol. 2000; 53:182-186.

29. Lee JH, Kim Y, Choi JW and Kim YS. Prevalence and prognostic significance of Epstein-Barr virus infection in classical Hodgkin's lymphoma: a meta-analysis. Arch Med Res. 2014; 45:417-431.

30. Alexander FE, Ricketts TJ, McKinney PA and Cartwright RA. Community lifestyle characteristics and incidence of Hodgkin's disease in young people. Int J Cancer. 1991; 48:10-14.

31. Crump C, Sundquist K, Sieh W, Winkleby MA and Sundquist J. Perinatal and family risk factors for Hodgkin lymphoma in childhood through young adulthood. Am J Epidemiol. 2012; 176:1147-1158.

32. Kharazmi E, Fallah M, Pukkala E, Olsen JH, Tryggvadottir L, Sundquist K, Tretli S and Hemminki K. Risk of familial classical Hodgkin lymphoma by relationship, histology, age, and sex: a joint study from five Nordic countries. Blood. 2015; 126:1990-1995.

33. Mack TM, Cozen W, Shibata DK, Weiss LM, Nathwani BN, Hernandez AM, Taylor CR, Hamilton AS, Deapen DM and Rappaport EB. Concordance for Hodgkin's disease in identical twins suggesting genetic susceptibility to the young-adult form of the disease. N Engl J Med. 1995; 332:413-418.

34. Cerhan JR and Slager SL. Familial predisposition and genetic risk factors for lymphoma. Blood. 2015; 126:22652273.

35. Schwartz CL, Friedman DL, McCarten K, Wolden SL, Voss $\mathrm{S}$, Constine LS and Chen L. Predictors of early response and event-free survival in Hodgkin lymphoma (HL): PET versus CT imaging. Journal of Clinical Oncology Conference: ASCO Annual Meeting. 2011; 29.

36. Barros MH, Scheliga A, De Matteo E, Minnicelli C, Soares FA, Zalcberg IR and Hassan R. Cell cycle characteristics and Epstein-Barr virus are differentially associated with aggressive and non-aggressive subsets of Hodgkin lymphoma in pediatric patients. Leukemia \& lymphoma.
2010; 51:1513-1522.

37. Chabay P, Pesce P, De Matteo E, Lombardi MG, Rey G and Preciado MV. No Influence of bcl-2, p53, and p21waf1 protein expression on the outcome of pediatric Hodgkin lymphomas. J Pediatr Hematol Oncol. 2006; 28:552-558.

38. Claviez A, Tiemann M, Peters J, Kreipe H, Schneppenheim $\mathrm{R}$ and Parwaresch $\mathrm{R}$. The impact of EBV, proliferation rate, and Bcl-2 expression in Hodgkin's disease in childhood. Ann Hematol. 1994; 68:61-66.

39. Joensuu H, Klemi PJ and Korkeila E. Prognostic value of DNA ploidy and proliferative activity in Hodgkin's disease. Am J Clin Pathol. 1988; 90:670-673.

40. Morente MM, Piris MA, Abraira V, Acevedo A, Aguilera B, Bellas C, Fraga M, Garcia-Del-Moral R, Gomez-Marcos F, Menarguez J, Oliva H, Sanchez-Beato M and Montalban C. Adverse clinical outcome in Hodgkin's disease is associated with loss of retinoblastoma protein expression, high Ki67 proliferation index, and absence of Epstein-Barr virus-latent membrane protein 1 expression. Blood. 1997; 90:2429-2436.

41. Tiemann M, Claviez A, Lüders H, Zimmermann M, Schellong G, Dörffel W and Parwaresch R. Proliferation characteristics in pediatric Hodgkin's lymphoma point to a cell cycle arrest in the G(1) phase. Mod Pathol. 2005; 18:1440-1447.

42. Barros MH, Zalcberg IR and Hassan R. Prognostic impact of CD15 expression and proliferative index in the outcome of children with classical Hodgkin lymphoma. Pediatr Blood Cancer. 2008; 50:428-429; author reply 430.

43. Dinand V, Malik A, Unni R, Arya LS, Pandey RM and Dawar R. Proliferative index and CD15 expression in pediatric classical Hodgkin lymphoma. Pediatr Blood Cancer. 2008; 50:280-283.

44. Bien E, Balcerska A, Adamkiewicz-Drozynska E, Rapala M, Krawczyk M and Stepinski J. Pre-treatment serum levels of interleukin-10, interleukin-12 and their ratio predict response to therapy and probability of event-free and overall survival in childhood soft tissue sarcomas, Hodgkin's lymphomas and acute lymphoblastic leukemias. Clin Biochem. 2009; 42:1144-1157.

45. Horie R, Watanabe $\mathrm{T}$, Morishita $\mathrm{Y}$, Ito $\mathrm{K}$, Ishida $\mathrm{T}$, Kanegae Y, Saito I, Higashihara M, Mori S and Kadin ME. Ligand-independent signaling by overexpressed CD30 drives NF-kappaB activation in Hodgkin-Reed-Sternberg cells. Oncogene. 2002; 21:2493-2503.

46. Gupta S, Yeh S, Chami R, Punnett A and Chung C. The prognostic impact of tumour-associated macrophages and Reed-Sternberg cells in paediatric Hodgkin lymphoma. Eur J Cancer. 2013; 49:3255-3261.

47. Nadali G, Tavecchia L, Zanolin E, Bonfante V, Viviani S, Camerini E, Musto P, Di Renzo N, Carotenuto M, Chilosi M, Krampera M and Pizzolo G. Serum level of the soluble form of the CD30 molecule identifies patients with Hodgkin's disease at high risk of unfavorable outcome. 
Blood. 1998; 91:3011-3016.

48. Albelda SM. Role of integrins and other cell adhesion molecules in tumor progression and metastasis. Lab Invest. 1993; 68:4-17.

49. Ruco LP, Pomponi D, Pigott R, Gearing AJ, Baiocchini $A$ and Baroni CD. Expression and cell distribution of the intercellular adhesion molecule, vascular cell adhesion molecule, endothelial leukocyte adhesion molecule, and endothelial cell adhesion molecule (CD31) in reactive human lymph nodes and in Hodgkin's disease. The American journal of pathology. 1992; 140:1337-1344.

50. Tacyildiz N, Yavuz G, Gozdasoglu S, Unal E, Ertem U, Duru F, Ikinciogullari A, Babacan E, Ensari A and Okcuoglu-Cavdar A. Serum levels and differential expression of intercellular adhesion molecule-1 in childhood leukemia and malignant lymphoma: prognostic importance and relationship with survival. Pediatr Hematol Oncol. 1999; 16:149-158.

51. Pui CH, Hudson M, Luo X, Wilimas J, Evans W and Crist WM. Serum interleukin-2 receptor levels in Hodgkin disease and other solid tumors of childhood. Leukemia. 1993; 7:1242-1244.

52. Abdelrazik N, Fouda M, Zaghloul MH and Abbas D. Serum level of intercellular adhesion molecule-1 in children with malignant lymphoma. Med Princ Pract. 2008; 17:233-238.

53. Elli M, Dagdemir A, Bozkurt C, Pinarli FG, Duzgun A, Ozmen ZC, Ertem U and Acar S. Serum osteopontin and CD44 levels in lymphoreticular malignancies in children. Bratisl Lek Listy. 2012; 113:534-538.

54. Taçyildiz N, Cavdar AO, Yavuz G, Gözdaoglu S, Unal E, Ertem U, Duru F, Ikinciogullari A, Babacan E, Kuzu I and Cin S. Serum levels and differential expression of CD44 in childhood leukemia and malignant lymphoma: correlation with prognostic criteria and survival. Pediatr Int. 2001; 43:354-360.

55. Sun $Z$ and Yang P. Role of imbalance between neutrophil elastase and alpha 1-antitrypsin in cancer development and progression. Lancet Oncol. 2004; 5:182-190.

56. Qi L, Cazares L, Johnson C, de Alarcon P, Kupfer GM and Semmes OJ. Serum protein expression profiling in pediatric Hodgkin lymphoma: a report from the Children's Oncology Group. Pediatr Blood Cancer. 2008; 51:216-221.

57. Ortaç R, Akta S, Diniz G, Erbay A and Vergin C. Prognostic role of natural killer cells in pediatric mixed cellularity and nodular sclerosing Hodgkin's disease. Anal Quant Cytol Histol. 2002; 24:249-253.

58. Ikincioullari A, Dou F, Babacan E, Oflaz G, Ertem U, Yavuz G, Unal E, Gözdaolu S, Taçyildiz N, Dademir A and Cavdar AO. Natural killer cell numbers and cytotoxic activity in pediatric Hodgkin disease. Pediatr Hematol Oncol. 2000; 17:133-139.

59. Sun SC and Ley SC. New insights into NF-kappaB regulation and function. Trends Immunol. 2008; 29:469478.
60. Sun SC. The noncanonical NF-kappaB pathway. Immunol Rev. 2012; 246:125-140.

61. Ding WX and Yin XM. Dissection of the multiple mechanisms of TNF-alpha-induced apoptosis in liver injury. J Cell Mol Med. 2004; 8:445-454.

62. Jost PJ and Ruland J. Aberrant NF-kappaB signaling in lymphoma: mechanisms, consequences, and therapeutic implications. Blood. 2007; 109:2700-2707.

63. Bargou RC, Leng C, Krappmann D, Emmerich F, Mapara MY, Bommert K, Royer HD, Scheidereit $\mathrm{C}$ and Dörken B. High-level nuclear NF-kappa B and Oct-2 is a common feature of cultured Hodgkin/Reed-Sternberg cells. Blood. 1996; 87:4340-4347.

64. Emmerich F, Meiser M, Hummel M, Demel G, Foss HD, Jundt F, Mathas S, Krappmann D, Scheidereit C, Stein H and Dörken B. Overexpression of I kappa B alpha without inhibition of NF-kappaB activity and mutations in the I kappa B alpha gene in Reed-Sternberg cells. Blood. 1999; 94:3129-3134.

65. Horton TM, Drachtman RA, Chen L, Cole PD, McCarten K, Voss S, Guillerman RP, Buxton A, Howard SC, Hogan SM, Sheehan AM, López-Terrada D, Mrazek MD, Agrawal $\mathrm{N}, \mathrm{Wu}$ MF, Liu H, et al. A phase 2 study of bortezomib in combination with ifosfamide/vinorelbine in paediatric patients and young adults with refractory/recurrent Hodgkin lymphoma: a Children's Oncology Group study. Br J Haematol. 2015; 170:118-122.

66. Ben Arush MW, Shafat I, Ben Barak A, Shalom RB, Vlodavsky I, Vlodavsky E and Ilan N. Plasma heparanase as a significant marker of treatment response in children with Hodgkin lymphoma: pilot study. Pediatr Hematol Oncol. 2009; 26:157-164.

67. Shafat I, Barak AB, Postovsky S, Elhasid R, Ilan N, Vlodavsky I and Arush MW. Heparanase levels are elevated in the plasma of pediatric cancer patients and correlate with response to anticancer treatment. Neoplasia. 2007; 9:909916.

68. Jelkmann W. Pitfalls in the measurement of circulating vascular endothelial growth factor. Clin Chem. 2001; 47:617-623.

69. Ben Arush MW, Ben Barak A, Maurice S and Livne E. Serum VEGF as a significant marker of treatment response in hodgkin lymphoma. Pediatr Hematol Oncol. 2007; 24:111-115.

70. Mizia-Malarz A, Sobol G, Janowska J, Wos H and Zahorska-Markiewicz B. Prognostic value of proangiogenic cytokines in children with lymphomas. Pediatr Blood Cancer. 2009; 53:1195-1199.

71. Fhu CW, Graham AM, Yap CT, Al-Salam S, Castella A, Chong SM and Lim YC. Reed-Sternberg cell-derived lymphotoxin- activates endothelial cells to enhance T-cell recruitment in classical Hodgkin lymphoma. Blood. 2014; 124:2973-2982.

72. Barros MH, Hassan R and Niedobitek G. Tumor-associated 
macrophages in pediatric classical Hodgkin lymphoma: association with Epstein-Barr virus, lymphocyte subsets, and prognostic impact. Clinical cancer research. 2012; 18:3762-3771.

73. Steidl C, Lee T, Shah SP, Farinha P, Han G, Nayar T, Delaney A, Jones SJ, Iqbal J, Weisenburger DD, Bast MA, Rosenwald A, Muller-Hermelink HK, Rimsza LM, Campo E, Delabie J, et al. Tumor-associated macrophages and survival in classic Hodgkin's lymphoma. N Engl J Med. 2010; 362:875-885.

74. Zameer MA, Premalata CS, Arunakumari B, Appaji L and Rao CR. Pediatric Hodgkin lymphoma in a South Indian regional cancer center: its immunomorphology, tumorassociated macrophages, and association with Epstein-Barr virus. Pediatr Hematol Oncol. 2015; 32:229-238.

75. Barros MH, Segges P, Vera-Lozada G, Hassan R and Niedobitek G. Macrophage polarization reflects $T$ cell composition of tumor microenvironment in pediatric classical Hodgkin lymphoma and has impact on survival. PLoS One. 2015; 10:e0124531.

76. Farina L, Rezzonico F, Spina F, Dodero A, Mazzocchi A, Crippa F, Alessi A, Dalto S, Viviani S and Corradini P. Serum thymus and activation-regulated chemokine level monitoring may predict disease relapse detected by PET scan after reduced-intensity allogeneic stem cell transplantation in patients with Hodgkin lymphoma. Biol Blood Marrow Transplant. 2014; 20:1982-1988.

77. Plattel WJ, van den Berg A, Visser L, van der Graaf AM, Pruim J, Vos H, Hepkema B, Diepstra A and van Imhoff GW. Plasma thymus and activation-regulated chemokine as an early response marker in classical Hodgkin's lymphoma. Haematologica. 2012; 97:410-415.

78. Jones K, Vari F, Keane C, Crooks P, Nourse JP, Seymour LA, Gottlieb D, Ritchie D, Gill D and Gandhi MK. Serum CD163 and TARC as disease response biomarkers in classical Hodgkin lymphoma. Clinical cancer research. 2013; 19:731-742.

79. Thompson LD, Fisher SI, Chu WS, Nelson A and Abbondanzo SL. HIV-associated Hodgkin lymphoma: a clinicopathologic and immunophenotypic study of 45 cases. Am J Clin Pathol. 2004; 121:727-738.

80. Watanabe K, Yamashita Y, Nakayama A, Hasegawa Y, Kojima H, Nagasawa T and Mori N. Varied B-cell immunophenotypes of Hodgkin/Reed-Sternberg cells in classic Hodgkin's disease. Histopathology. 2000; 36:353361.

81. Gharbaran R, Goy A, Tanaka T, Park J, Kim C, Hasan N, Vemulapalli S, Sarojini S, Tuluc M, Nalley K, Bhattacharyya P, Pecora A and Suh KS. Fibroblast growth factor-2 (FGF2) and syndecan-1 (SDC1) are potential biomarkers for putative circulating CD15+/CD30+ cells in poor outcome Hodgkin lymphoma patients. J Hematol Oncol. 2013; 6:62.

82. Vassilakopoulos TP, Kyrtsonis MC, Papadogiannis A, Nadali G, Angelopoulou MK, Tzenou T, Dimopoulou MN,
Siakantaris MP, Kontopidou FN, Kalpadakis C, Kokoris SI, Dimitriadou EM, Tsaftaridis P, Pizzolo G and Pangalis GA. Serum levels of soluble syndecan-1 in Hodgkin's lymphoma. Anticancer Res. 2005; 25:4743-4746.

83. Andrie E, Michos A, Kalampoki V, Pourtsidis A, Moschovi M, Polychronopoulou S, Athanasiadou-Piperopoulou F, Kalmanti M, Hatzakis A, Paraskevis D, Nieters A and Petridou ET. Genetic variants in immunoregulatory genes and risk for childhood lymphomas. Eur J Haematol. 2009; 83:334-342.

84. Arias MA, Rey Nores JE, Vita N, Stelter F, Borysiewicz LK, Ferrara P and Labéta MO. Cutting edge: human B cell function is regulated by interaction with soluble CD14: opposite effects on IgG1 and IgE production. J Immunol. 2000; 164:3480-3486.

85. Baldini M, Lohman IC, Halonen M, Erickson RP, Holt PG and Martinez FD. A Polymorphism* in the 5' flanking region of the CD14 gene is associated with circulating soluble CD14 levels and with total serum immunoglobulin E. Am J Respir Cell Mol Biol. 1999; 20:976-983.

86. Cozen W, Gill PS, Salam MT, Nieters A, Masood R, Cockburn MG, Gauderman WJ, Martínez-Maza O, Nathwani BN, Pike MC, Van Den Berg DJ, Hamilton AS, Deapen DM and Mack TM. Interleukin-2, interleukin-12, and interferon-gamma levels and risk of young adult Hodgkin lymphoma. Blood. 2008; 111:3377-3382.

87. Stepensky P, Weintraub M, Yanir A, Revel-Vilk S, Krux F, Huck K, Linka RM, Shaag A, Elpeleg O, Borkhardt A and Resnick IB. IL-2-inducible T-cell kinase deficiency: clinical presentation and therapeutic approach. Haematologica. 2011; 96:472-476.

88. Alme C, Satwani P, Alobeid B, Bhagat G and Kelly KM. Atypical Clinical Course in Pediatric Hodgkin Lymphoma: Association With Germline Mutations in Interleukin-2inducible T-Cell Kinase. J Pediatr Hematol Oncol. 2015; 37:507-508.

89. Best T, Li D, Skol AD, Kirchhoff T, Jackson SA, Yasui Y, Bhatia S, Strong LC, Domchek SM, Nathanson KL, Olopade OI, Huang RS, Mack TM, Conti DV, Offit K, Cozen W, et al. Variants at 6q21 implicate PRDM1 in the etiology of therapy-induced second malignancies after Hodgkin's lymphoma. Nat Med. 2011; 17:941-943.

90. Varszegi D, Duga B, Melegh BI, Sumegi K, Kisfali P, Maasz A and Melegh B. Hodgkin disease therapy induced second malignancy susceptibility 6q21 functional variants in roma and hungarian population samples. Pathol Oncol Res. 2014; 20:529-533.

91. Mertens AC, Mitby PA, Radloff G, Jones IM, Perentesis J, Kiffmeyer WR, Neglia JP, Meadows A, Potter JD, Friedman D, Yasui Y, Robison LL and Davies SM. XRCC1 and glutathione-S-transferase gene polymorphisms and susceptibility to radiotherapy-related malignancies in survivors of Hodgkin disease. Cancer. 2004; 101:14631472.

92. Tebbi CK, Mendenhall N, London WB, Williams JL, de 
Alarcon PA, Chauvenet AR and Group CsO. Treatment of stage I, IIA, IIIA1 pediatric Hodgkin disease with doxorubicin, bleomycin, vincristine and etoposide (DBVE) and radiation: a Pediatric Oncology Group (POG) study. Pediatr Blood Cancer. 2006; 46:198-202.

93. Mauz-Körholz C, Hasenclever D, Dörffel W, Ruschke K, Pelz T, Voigt A, Stiefel M, Winkler M, Vilser C, Dieckmann K, Karlén J, Bergsträsser E, Fosså A, Mann G, Hummel M, Klapper W, et al. Procarbazine-free OEPACOPDAC chemotherapy in boys and standard OPPACOPP in girls have comparable effectiveness in pediatric Hodgkin's lymphoma: the GPOH-HD-2002 study. J Clin Oncol. 2010; 28:3680-3686.

94. Metzger ML, Weinstein HJ, Hudson MM, Billett AL, Larsen EC, Friedmann A, Howard SC, Donaldson SS, Krasin MJ, Kun LE, Marcus KJ, Yock TI, Tarbell N, Billups CA, Wu J and Link MP. Association between radiotherapy vs no radiotherapy based on early response to VAMP chemotherapy and survival among children with favorable-risk Hodgkin lymphoma. JAMA. 2012; 307:2609-2616.

95. Castellino SM, Geiger AM, Mertens AC, Leisenring WM, Tooze JA, Goodman P, Stovall M, Robison LL and Hudson MM. Morbidity and mortality in long-term survivors of Hodgkin lymphoma: a report from the Childhood Cancer Survivor Study. Blood. 2011; 117:1806-1816.

96. Donaldson SS and Kaplan HS. Complications of treatment of Hodgkin's disease in children. Cancer Treat Rep. 1982; 66:977-989.

97. Mauch PM, Weinstein H, Botnick L, Belli J and Cassady JR. An evaluation of long-term survival and treatment complications in children with Hodgkin's disease. Cancer. 1983; 51:925-932.

98. Dörffel W, Rühl U, Lüders H, Claviez A, Albrecht M, Bökkerink J, Holte H, Karlen J, Mann G, Marciniak H, Niggli F, Schmiegelow K, Schwarze EW, Pötter R, Wickmann L and Schellong G. Treatment of children and adolescents with Hodgkin lymphoma without radiotherapy for patients in complete remission after chemotherapy: final results of the multinational trial GPOH-HD95. J Clin Oncol. 2013; 31:1562-1568.

99. Wolden SL, Chen L, Kelly KM, Herzog P, Gilchrist GS, Thomson J, Sposto R, Kadin ME, Hutchinson RJ and Nachman J. Long-term results of CCG 5942: a randomized comparison of chemotherapy with and without radiotherapy for children with Hodgkin's lymphoma - a report from the Children's Oncology Group. J Clin Oncol. 2012; 30:31743180 .

100. Schwartz CL, Constine LS, Villaluna D, London WB, Hutchison RE, Sposto R, Lipshultz SE, Turner CS, deAlarcon PA and Chauvenet A. A risk-adapted, response-based approach using ABVE-PC for children and adolescents with intermediate- and high-risk Hodgkin lymphoma: the results of P9425. Blood. 2009; 114:20512059.
101. Engert A, Plütschow A, Eich HT, Lohri A, Dörken B, Borchmann P, Berger B, Greil R, Willborn KC, Wilhelm M, Debus J, Eble MJ, Sökler M, Ho A, Rank A, Ganser A, et al. Reduced treatment intensity in patients with earlystage Hodgkin's lymphoma. N Engl J Med. 2010; 363:640652.

102. Friedman DL, Chen L, Wolden S, Buxton A, McCarten K, FitzGerald TJ, Kessel S, De Alarcon PA, Chen AR, Kobrinsky N, Ehrlich P, Hutchison RE, Constine LS and Schwartz CL. Dose-intensive response-based chemotherapy and radiation therapy for children and adolescents with newly diagnosed intermediate-risk hodgkin lymphoma: a report from the Children's Oncology Group Study AHOD0031. J Clin Oncol. 2014; 32:3651-3658.

103. O'Brien MM, Donaldson SS, Balise RR, Whittemore AS and Link MP. Second malignant neoplasms in survivors of pediatric Hodgkin's lymphoma treated with low-dose radiation and chemotherapy. J Clin Oncol. 2010; 28:12321239.

104. Hudson MM, Krasin M, Link MP, Donaldson SS, Billups C, Merchant TE, Kun L, Billet AL, Kaste S, Tarbell NJ, Howard S, Friedmann AM, Hurwitz CA, Young JA, Marcus KC, Rai S, et al. Risk-adapted, combined-modality therapy with VAMP/COP and response-based, involvedfield radiation for unfavorable pediatric Hodgkin's disease. J Clin Oncol. 2004; 22:4541-4550.

105. Kelly KM, Sposto R, Hutchinson R, Massey V, McCarten $\mathrm{K}$, Perkins S, Lones M, Villaluna D and Weiner M. BEACOPP chemotherapy is a highly effective regimen in children and adolescents with high-risk Hodgkin lymphoma: a report from the Children's Oncology Group. Blood. 2011; 117:2596-2603.

106. Casasnovas O, Brice P, Bouabdallah R, Salles AG, Stamatoullas A, Dupuis J and Reman O. (2015). Randomized Phase III Study Comparing an Early PET Driven Treatment De-Escalation to a Not PET-Monitored Strategy in Patients with Advanced Stages Hodgkin Lymphoma: Interim Analysis of the AHL2011 Lysa Study. 57th ASH Annual Meeting. (Orlando, FL).

107. Tebbi CK, London WB, Friedman D, Villaluna D, De Alarcon PA, Constine LS, Mendenhall NP, Sposto R, Chauvenet A and Schwartz CL. Dexrazoxane-associated risk for acute myeloid leukemia/myelodysplastic syndrome and other secondary malignancies in pediatric Hodgkin's disease. J Clin Oncol. 2007; 25:493-500.

108. Harris RE, Termuhlen AM, Smith LM, Lynch J, Henry MM, Perkins SL, Gross TG, Warkentin P, Vlachos A, Harrison L and Cairo MS. Autologous peripheral blood stem cell transplantation in children with refractory or relapsed lymphoma: results of Children's Oncology Group study A5962. Biol Blood Marrow Transplant. 2011; 17:249258.

109. Schellong G, Dörffel W, Claviez A, Körholz D, Mann G, Scheel-Walter HG, Bökkerink JP, Riepenhausen M, Lüders H, Pötter R, Rühl U and DAL/GPOH. Salvage therapy of 
progressive and recurrent Hodgkin's disease: results from a multicenter study of the pediatric DAL/GPOH-HD study group. J Clin Oncol. 2005; 23:6181-6189.

110. Metzger ML, Hudson MM, Krasin MJ, Wu J, Kaste SC, Kun LE, Sandlund JT and Howard SC. Initial response to salvage therapy determines prognosis in relapsed pediatric Hodgkin lymphoma patients. Cancer. 2010; 116:4376-4384.

111. Claviez A, Klingebiel T, Beyer J, Nürnberger W, Ehninger G, Suttorp M, Dreger P, Dörffel W and Schmitz N. Allogeneic peripheral blood stem cell transplantation following fludarabine-based conditioning in six children with advanced Hodgkin's disease. Ann Hematol. 2004; 83:237-241.

112. Belgaumi A, Al-Kofide AA, Khafaga Y, Joseph N, Jamil-Malik R, Siddiqui KS and Sabbah RS. Clinical characteristics and outcome of pediatric patients with stage IV Hodgkin lymphoma. Hematology/oncology and stem cell therapy. 2009; 2:278-284.

113. Gorde-Grosjean S, Oberlin O, Leblanc T, Pacquement H, Donadieu J, Lambilliotte A, Schell M, Dommange F, Munzer M, Paillard C, Schmitt C, Lutz P, Edan C, Ansoborlo S, Stephan JL, Michel G, et al. Outcome of children and adolescents with recurrent/refractory classical Hodgkin lymphoma, a study from the Société Française de Lutte contre le Cancer des Enfants et des Adolescents (SFCE). Br J Haematol. 2012; 158:649-656.

114. Lieskovsky YE, Donaldson SS, Torres MA, Wong RM, Amylon MD, Link MP and Agarwal R. High-dose therapy and autologous hematopoietic stem-cell transplantation for recurrent or refractory pediatric Hodgkin's disease: results and prognostic indices. J Clin Oncol. 2004; 22:4532-4540.

115. Satwani P, Jin Z, Martin PL, Bhatia M, Garvin JH, George D, Chaudhury S, Talano J, Morris E, Harrison L, Sosna J, Peterson M, Militano O, Foley S, Kurtzberg $\mathrm{J}$ and Cairo MS. Sequential myeloablative autologous stem cell transplantation and reduced intensity allogeneic hematopoietic cell transplantation is safe and feasible in children, adolescents and young adults with poorrisk refractory or recurrent Hodgkin and non-Hodgkin lymphoma. Leukemia. 2015; 29:448-455.

116. Linch DC, Winfield D, Goldstone AH, Moir D, Hancock B, McMillan A, Chopra R, Milligan D and Hudson GV. Dose intensification with autologous bone-marrow transplantation in relapsed and resistant Hodgkin's disease: results of a BNLI randomised trial. Lancet. 1993; 341:1051-1054.

117. Moskowitz $\mathrm{CH}$, Nimer SD, Zelenetz AD, Trippett $\mathrm{T}$, Hedrick EE, Filippa DA, Louie D, Gonzales M, Walits J, Coady-Lyons N, Qin J, Frank R, Bertino JR, Goy A, Noy A, O'Brien JP, et al. A 2-step comprehensive high-dose chemoradiotherapy second-line program for relapsed and refractory Hodgkin disease: analysis by intent to treat and development of a prognostic model. Blood. 2001; 97:616623.

118. Trippett TM, Schwartz CL, Guillerman RP, Gamis AS, Gardner S, Hogan S, London WB, Chen L and de Alarcon
P. Ifosfamide and vinorelbine is an effective reinduction regimen in children with refractory/relapsed Hodgkin lymphoma, AHOD00P1: a children's oncology group report. Pediatr Blood Cancer. 2015; 62:60-64.

119. Cole PD, Schwartz CL, Drachtman RA, de Alarcon PA, Chen L and Trippett TM. Phase II study of weekly gemcitabine and vinorelbine for children with recurrent or refractory Hodgkin's disease: a children's oncology group report. J Clin Oncol. 2009; 27:1456-1461.

120. Diefenbach $\mathrm{C}$ and Advani R. Customized targeted therapy in Hodgkin lymphoma: hype or hope? Hematol Oncol Clin North Am. 2014; 28:105-122.

121. Francisco JA, Cerveny CG, Meyer DL, Mixan BJ, Klussman K, Chace DF, Rejniak SX, Gordon KA, DeBlanc R, Toki BE, Law CL, Doronina SO, Siegall CB, Senter PD and Wahl AF. cAC10-vcMMAE, an anti-CD30-monomethyl auristatin $\mathrm{E}$ conjugate with potent and selective antitumor activity. Blood. 2003; 102:1458-1465.

122. Younes A, Connors JM, Park SI, Fanale M, O’Meara MM, Hunder NN, Huebner D and Ansell SM. Brentuximab vedotin combined with ABVD or AVD for patients with newly diagnosed Hodgkin's lymphoma: a phase 1, openlabel, dose-escalation study. Lancet Oncol. 2013; 14:13481356.

123. Moskowitz $\mathrm{CH}$, Nademanee A, Masszi T, Agura E, Holowiecki J, Abidi MH, Chen AI, Stiff P, Gianni AM, Carella A, Osmanov D, Bachanova V, Sweetenham J, Sureda A, Huebner D, Sievers EL, et al. Brentuximab vedotin as consolidation therapy after autologous stem-cell transplantation in patients with Hodgkin's lymphoma at risk of relapse or progression (AETHERA): a randomised, double-blind, placebo-controlled, phase 3 trial. Lancet. 2015; 385:1853-1862.

124. Cvek B and Dvorak Z. The ubiquitin-proteasome system (UPS) and the mechanism of action of bortezomib. Curr Pharm Des. 2011; 17:1483-1499.

125. Mendler JH, Kelly J, Voci S, Marquis D, Rich L, Rossi RM, Bernstein SH, Jordan CT, Liesveld J, Fisher RI and Friedberg JW. Bortezomib and gemcitabine in relapsed or refractory Hodgkin's lymphoma. Ann Oncol. 2008; 19:1759-1764.

126. Boll B, Hansen H, Heuck F, Reiners K, Borchmann P, Rothe A, Engert A and Pogge von Strandmann E. The fully human anti-CD30 antibody 5F11 activates NF- kappa $\mathrm{B}$ and sensitizes lymphoma cells to bortezomib-induced apoptosis. Blood. 2005; 106:1839-1842.

127. Buglio D, Georgakis GV, Hanabuchi S, Arima K, Khaskhely NM, Liu YJ and Younes A. Vorinostat inhibits STAT6-mediated TH2 cytokine and TARC production and induces cell death in Hodgkin lymphoma cell lines. Blood. 2008; 112:1424-1433.

128. Oki Y, Buglio D, Zhang J, Ying Y, Zhou S, Sureda A, Ben-Yehuda D, Zinzani PL, Prince HM, Harrison SJ, Kirschbaum M, Johnston PB, Shen A, von Tresckow B and Younes A. Immune regulatory effects of panobinostat in 
patients with Hodgkin lymphoma through modulation of serum cytokine levels and T-cell PD1 expression. Blood Cancer J. 2014; 4:e236.

129. Kirschbaum MH, Goldman BH, Zain JM, Cook JR, Rimsza LM, Forman SJ and Fisher RI. A phase 2 study of vorinostat for treatment of relapsed or refractory Hodgkin lymphoma: Southwest Oncology Group Study S0517. Leukemia \& lymphoma. 2012; 53:259-262.

130. Younes A, Sureda A, Ben-Yehuda D, Zinzani PL, Ong TC, Prince HM, Harrison SJ, Kirschbaum M, Johnston P, Gallagher J, Le Corre C, Shen A and Engert A. Panobinostat in patients with relapsed/refractory Hodgkin's lymphoma after autologous stem-cell transplantation: results of a phase II study. J Clin Oncol. 2012; 30:2197-2203.

131. Zhang QL, Wang L, Zhang YW, Jiang XX, Yang F, Wu WL, Janin A, Chen Z, Shen ZX, Chen SJ and Zhao WL. The proteasome inhibitor bortezomib interacts synergistically with the histone deacetylase inhibitor suberoylanilide hydroxamic acid to induce T-leukemia/lymphoma cells apoptosis. Leukemia. 2009; 23:1507-1514.

132. Diaz LA, Coughlin CM, Weil SC, Fishel J, Gounder MM, Lawrence S, Azad N, O'Shannessy DJ, Grasso L, Wustner J, Ebel W and Carvajal RD. A first-in-human phase I study of MORAb-004, a monoclonal antibody to endosialin in patients with advanced solid tumors. Clinical cancer research. 2015; 21:1281-1288.

133. MacFadyen JR, Haworth O, Roberston D, Hardie D, Webster MT, Morris HR, Panico M, Sutton-Smith M, Dell A, van der Geer P, Wienke D, Buckley CD and Isacke CM. Endosialin (TEM1, CD248) is a marker of stromal fibroblasts and is not selectively expressed on tumour endothelium. FEBS Lett. 2005; 579:2569-2575.

134. Rouleau C, Curiel M, Weber W, Smale R, Kurtzberg L, Mascarello J, Berger C, Wallar G, Bagley R, Honma N, Hasegawa K, Ishida I, Kataoka S, Thurberg BL, Mehraein $\mathrm{K}$, Horten B, et al. Endosialin protein expression and therapeutic target potential in human solid tumors: sarcoma versus carcinoma. Clinical cancer research. 2008; 14:72237236.

135. Rybinski K, Imtiyaz HZ, Mittica B, Drozdowski B, Fulmer J, Furuuchi K, Fernando S, Henry M, Chao Q, Kline B, Albone E, Wustner J, Lin J, Nicolaides NC, Grasso L and Zhou Y. Targeting endosialin/CD248 through antibodymediated internalization results in impaired pericyte maturation and dysfunctional tumor microvasculature. Oncotarget. 2015; 6:25429-25440. doi:10.18632/ oncotarget. 4559.

136. Ansell SM, Lesokhin AM, Borrello I, Halwani A, Scott EC, Gutierrez M, Schuster SJ, Millenson MM, Cattry D, Freeman GJ, Rodig SJ, Chapuy B, Ligon AH, Zhu L, Grosso JF, Kim SY, et al. PD-1 blockade with nivolumab in relapsed or refractory Hodgkin's lymphoma. N Engl J Med. 2015; 372:311-319.

137. Ng AK, Kenney LB, Gilbert ES and Travis LB. Secondary malignancies across the age spectrum. Semin Radiat Oncol.
2010; 20:67-78.

138. Omer B, Kadan-Lottick NS, Roberts KB, Wang R, Demsky C, Kupfer GM, Cooper D, Seropian S and Ma X. Patterns of subsequent malignancies after Hodgkin lymphoma in children and adults. Br J Haematol. 2012; 158:615-625.

139. Bhatia S, Yasui Y, Robison LL, Birch JM, Bogue MK, Diller L, DeLaat C, Fossati-Bellani F, Morgan E, Oberlin O, Reaman G, Ruymann FB, Tersak J, Meadows AT and Group LES. High risk of subsequent neoplasms continues with extended follow-up of childhood Hodgkin's disease: report from the Late Effects Study Group. J Clin Oncol. 2003; 21:4386-4394.

140. Metayer C, Lynch CF, Clarke EA, Glimelius B, Storm H, Pukkala E, Joensuu T, van Leeuwen FE, van't Veer MB, Curtis RE, Holowaty EJ, Andersson M, Wiklund T, Gospodarowicz M and Travis LB. Second cancers among long-term survivors of Hodgkin's disease diagnosed in childhood and adolescence. J Clin Oncol. 2000; 18:24352443.

141. Neglia JP, Friedman DL, Yasui Y, Mertens AC, Hammond S, Stovall M, Donaldson SS, Meadows AT and Robison LL. Second malignant neoplasms in five-year survivors of childhood cancer: childhood cancer survivor study. J Natl Cancer Inst. 2001; 93:618-629.

142. Bhatia S. Therapy-related myelodysplasia and acute myeloid leukemia. Semin Oncol. 2013; 40:666-675.

143. Pedersen-Bjergaard J and Philip P. Balanced translocations involving chromosome bands $11 \mathrm{q} 23$ and $21 \mathrm{q} 22$ are highly characteristic of myelodysplasia and leukemia following therapy with cytostatic agents targeting at DNAtopoisomerase II. Blood. 1991; 78:1147-1148.

144. Schellong G and Riepenhausen M. Late effects after therapy of Hodgkin's disease: update 2003/04 on overwhelming post-splenectomy infections and secondary malignancies. Klin Padiatr. 2004; 216:364-369.

145. Dörffel W, Riepenhausenl M, Lüders H, Brämswig J and Schellong G. Secondary Malignancies Following Treatment for Hodgkin's Lymphoma in Childhood and Adolescence. Dtsch Arztebl Int. 2015; 112:320-327, i.

146. Baker KS, DeFor TE, Burns LJ, Ramsay NK, Neglia JP and Robison LL. New malignancies after blood or marrow stem-cell transplantation in children and adults: incidence and risk factors. J Clin Oncol. 2003; 21:1352-1358.

147. Barnard DR, Lange B, Alonzo TA, Buckley J, Kobrinsky JN, Gold S, Neudorf S, Sanders J, Burden L and Woods WG. Acute myeloid leukemia and myelodysplastic syndrome in children treated for cancer: comparison with primary presentation. Blood. 2002; 100:427-434.

148. Brusa G, Zuffa E, Hattinger CM, Serra M, Remondini D, Castellani G, Righi S, Campidelli C, Pileri S, Zinzani PL, Gabriele A, Mancini M, Corrado P, Barbieri E and Santucci MA. Genomic imbalances associated with secondary acute leukemias in Hodgkin lymphoma. Oncol Rep. 2007; 18:1427-1434. 
149. Ries LAG SM, Gurney JG, Linet M, Tamra T, Young JL, Bunin GR (eds). (1999). Cancer Incidence and Survival among Children and Adolescents: United States SEER Program 1975-1995. (National Cancer Institute, SEER Program. NIH Pub. No. 99-4649. Bethesda, MD.

150. Board PDQPTE. (2002). Childhood Hodgkin Lymphoma Treatment (PDQ(R)): Health Professional Version. PDQ Cancer Information Summaries. (Bethesda (MD): National Cancer Institute (US)).

151. Armstrong AA, Alexander FE, Cartwright R, Angus B, Krajewski AS, Wright DH, Brown I, Lee F, Kane E and Jarrett RF. Epstein-Barr virus and Hodgkin's disease: further evidence for the three disease hypothesis. Leukemia. 1998; 12:1272-1276.

152. Tebbi CK, Mendenhall NP, London WB, Williams JL, Hutchison RE, Fitzgerald TJ, de Alarcon PA, Schwartz $\mathrm{C}$ and Chauvenet A. Response-dependent and reduced treatment in lower risk Hodgkin lymphoma in children and adolescents, results of P9426: a report from the Children's Oncology Group. Pediatr Blood Cancer. 2012; 59:12591265.

153. Locatelli F NK, Rosolen A, Landman-Parker J, Aladjidi N, Beishuizen A, Daw S, Gore L, Franklin A, Fasanmade A, Wang J, Sachs J, and Mauz-Koerholz C. Phase 1/2 Study Of Brentuximab Vedotin In Pediatric Patients With Relapsed Or Refractory (R/R) Hodgkin Lymphoma (HL) Or Systemic Anaplastic Large-Cell Lymphoma (sALCL): Preliminary Phase 2 Data For Brentuximab Vedotin $1.8 \mathrm{Mg} / \mathrm{Kg}$ In The HL Study Arm Blood. 2013; 4378 -4378.
154. Constine LS, Tarbell N, Hudson MM, Schwartz C, Fisher SG, Muhs AG, Basu SK, Kun LE, Ng A, Mauch P, Sandhu A, Culakova E, Lyman G and Mendenhall N. Subsequent malignancies in children treated for Hodgkin's disease: associations with gender and radiation dose. Int J Radiat Oncol Biol Phys. 2008; 72:24-33.

155. Green DM, Hyland A, Barcos MP, Reynolds JA, Lee RJ, Hall BC and Zevon MA. Second malignant neoplasms after treatment for Hodgkin's disease in childhood or adolescence. J Clin Oncol. 2000; 18:1492-1499.

156. Wolden SL, Lamborn KR, Cleary SF, Tate DJ and Donaldson SS. Second cancers following pediatric Hodgkin's disease. J Clin Oncol. 1998; 16:536-544.

157. Bhatia S, Robison LL, Oberlin O, Greenberg M, Bunin G, Fossati-Bellani F and Meadows AT. Breast cancer and other second neoplasms after childhood Hodgkin's disease. N Engl J Med. 1996; 334:745-751.

158. Sankila R, Garwicz S, Olsen JH, Döllner H, Hertz H, Kreuger A, Langmark F, Lanning M, Möller T and Tulinius H. Risk of subsequent malignant neoplasms among 1,641 Hodgkin's disease patients diagnosed in childhood and adolescence: a population-based cohort study in the five Nordic countries. Association of the Nordic Cancer Registries and the Nordic Society of Pediatric Hematology and Oncology. J Clin Oncol. 1996; 14:1442-1446. 